\title{
INFRASTRUCTURE FINANCING IN SOUTH ASIA
}

Shikha Jha and Rosa Mia Arao

NO. 59

September 2018
ADB SOUTH ASIA WORKING PAPER SERIES 
ADB South Asia Working Paper Series

\section{Infrastructure Financing in South Asia}

Shikha Jha and Rosa Mia Arao

No. 59 | September 2018
Shikha Jha, principal economist,

Economic Research and Regional Cooperation Department, Asian Development Bank (ADB).

Rosa Mia Arao, former research associate at the Public Management, Financial Sector and Trade Division, South Asia Department, ADB. 
(C) 2018 Asian Development Bank 6 ADB Avenue, Mandaluyong City, 1550 Metro Manila, Philippines

Tel +632632 4444; Fax +6326362444

www.adb.org

Some rights reserved. Published in 2018.

ISSN 2071-7202 (print), 2218-2675 (electronic)

Publication Stock No. WPS189514-2

DOI: http://dx.doi.org/10.22617/WPS189514-2

The views expressed in this publication are those of the authors and do not necessarily reflect the views and policies of the Asian Development Bank (ADB) or its Board of Governors or the governments they represent.

ADB does not guarantee the accuracy of the data included in this publication and accepts no responsibility for any consequence of their use. The mention of specific companies or products of manufacturers does not imply that they are endorsed or recommended by ADB in preference to others of a similar nature that are not mentioned.

By making any designation of or reference to a particular territory or geographic area, or by using the term "country" in this document, $A D B$ does not intend to make any judgments as to the legal or other status of any territory or area.

This work is available under the Creative Commons Attribution 3.0 IGO license (CC BY 3.0 IGO)

https://creativecommons.org/licenses/by/3.o/igo/. By using the content of this publication, you agree to be bound by the terms of this license. For attribution, translations, adaptations, and permissions, please read the provisions and terms of use at https://www.adb.org/terms-use\#openaccess.

This CC license does not apply to non-ADB copyright materials in this publication. If the material is attributed to another source, please contact the copyright owner or publisher of that source for permission to reproduce it. $\mathrm{ADB}$ cannot be held liable for any claims that arise as a result of your use of the material.

Please contact pubsmarketing@adb.org if you have questions or comments with respect to content, or if you wish to obtain copyright permission for your intended use that does not fall within these terms, or for permission to use the ADB logo.

The ADB South Asia Working Paper Series is a forum for ongoing and recently completed research and policy studies undertaken in $\mathrm{ADB}$ or on its behalf. It is meant to enhance greater understanding of current important economic and development issues in South Asia, promote policy dialogue among stakeholders, and facilitate reforms and development management.

The ADB South Asia Working Paper Series is a quick-disseminating, informal publication whose titles could subsequently be revised for publication as articles in professional journals or chapters in books. The series is maintained by the South Asia Department. The series will be made available on the ADB website and on hard copy.

Notes:

In this publication, “\$” refers to United States dollars.

Corrigenda to ADB publications may be found at http://www.adb.org/publications/corrigenda. 


\section{CONTENTS}

TABLES, FIGURES, AND BOXES iv

ACKNOWLEDGMENTS V v v v v

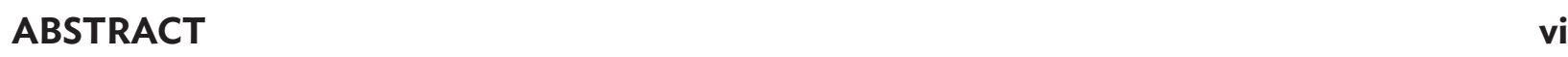

ABBREVIATIONS vii

$\begin{array}{lll}\text { I. INTRODUCTION } & 1\end{array}$

II. DEVELOPMENT OF INFRASTRUCTURE IN SOUTH ASIA: TRENDS AND QUALITY 2

III. PUBLIC AND PRIVATE SECTOR FINANCING

$\begin{array}{ll}\text { A. Corruption in Public Infrastructure Provision } & 14\end{array}$

$\begin{array}{ll}\text { B. Leveraging the Private Sector } & 15\end{array}$

IV. DRIVERS OF INFRASTRUCTURE INVESTMENT 21

A. Total Public and Private Investment 21

$\begin{array}{ll}\text { B. Private Investment by Sector } & 24\end{array}$

V. CONCLUSIONS AND POLICY IMPLICATIONS 30

APPENDIX: DEFINITION OF VARIABLES

$\begin{array}{lr}\text { REFERENCES } & 35\end{array}$ 


\section{TABLES, FIGURES, AND BOXES}

\section{TABLES}

1 South Asia Gross Domestic Product Growth—Long-Term Trends, Annual Variations 1

2 State Capture and Administrative Corruption in the Project Cycle 14

3 Cost of Doing Business, World Regions, 2017

4 Panel Estimation Results, Ordinary Least Squares Fixed Effects 23

5 Panel Estimation Results: Private Participation in Infrastructure 25

6 Panel Estimation Results: Private Participation in Infrastructure, Energy Sector 27

7 Panel Estimation Results: Private Participation in Infrastructure, Transport Sector 28

8 Panel Estimation Results: Private Participation in Infrastructure, Telecommunication Sector 29

\section{FIGURES}

1 Infrastructure Investment Needs of Developing Asia, 2016-2030 2

2 Access to Infrastructure Services, World Regions, 2014-2015 3

3 Railway and Road Length, Selected Asian Economies, 2011 and 2012

4 Logistical Performance, World Regions, 2007 and 2016

5 Logistical Performance, South Asian Countries, 2007 and 2016

6 Trends in Infrastructure Quality, South Asia, 2007-2016 6

7 Access to Electricity across Developing Asia, 2014

8 Number of Electrical Outages Faced by Firms in a Typical Month, World Regions, 2017

9 Quality of Electricity Supply and Transportation for Firms in South Asian Countries, Latest Year 7

10 Quality of Water Supply and Shipping for Firms in South Asian Countries, Latest Year 8

11 Access to Improved Water Sources, World Regions, 2015

12 Access to Improved Sanitation Facilities, World Regions, 2015

13 Trends in Infrastructure Investment in India, 1960-2015 11

14 Fiscal Balance, 2007 and 2016

15 General Government Debt, 2007 and 2016

16 Public-Private Partnership Investment in Developing Asia, 1991-2015 16

17 Public-Private Partnership Investment in Developing Asia, by Subregion 17

18 Number of Days for Doing Business, States in India, 2017

19 Better Quality of Infrastructure Associated with Larger Share of Credit
for Construction vis-à-vis Other Areas

\section{BOXES}

1 Building a Pipeline of Bankable Private Sector Projects 15

2 Readiness for Public-Private Partnerships $\quad 18$ 


\section{ACKNOWLEDGMENTS}

We would like to thank Bruno Carrasco, director, Public Management, Financial Sector, and Trade Division (SAPF) of the South Asia Department, Asian Development Bank (ADB) for many insightful discussions and brainstorming sessions that enriched the quality of this paper. For productive discussions, advice, and comments, we are grateful to Abdul Abiad (economic advisor, Office of the Chief Economist); Yi Jiang (senior economist, Development Economics and Indicators Division); Navendu Karan (senior public management economist, SAPF; Vivek Rao (principal financial sector specialist, SAPF); and Zhigang Li (social sector economist, Human and Social Development Division), all from ADB; Koki Hirota (chief economist, Japan International Cooperation Agency [JICA]); Hiroshi Takeuchi (senior research fellow, JICA Research Institute, Japan); Han Li (professor, Southwestern University of Finance and Economics, People's Republic of China [PRC]); Hangtian Xu (associate professor, Hunan University, PRC); and Anupam Rastogi (senior professor, Finance, Narsee Monjee Institute of Management Studies, India). Sheila Marie D. Foronda-Mariano of the South Asia Department, ADB provided excellent assistance in the editing and publication process. We take the responsibility for any remaining errors and omissions. 


\begin{abstract}
South Asia seems to defy the stylized fact that development of infrastructure is an effective driver of sustained economic growth. Despite the severe and persistent shortage of quality infrastructure, it is the fastest-growing region in the world. This trend cannot continue. To sustain growth and deal with climate change, South Asia needs to invest almost $9 \%$ of its gross domestic product on infrastructure development over 2016-2030, higher than most other subregions of Asia. This paper discusses public and private sector financing of infrastructure, and examines the factors driving infrastructure investment in this subregion. Using a panel of three large South Asian countries, namely, Bangladesh, India, and Sri Lanka, the paper finds that the stage of economic development, market size, access to finance, and the quality of institutions are the key determinants of total private and overall infrastructure investment. The results also reinforce the importance of a supportive enabling environment (better policies, institutions, and regulations) for private sector participation in infrastructure.
\end{abstract}

\title{
JOURNAL OF ECONOMIC LITERATURE CLASSIFICATION CODES
}

D25, G11, H54, R42

\section{KEYWORDS}

Infrastructure, finance, government, private sector, institutions, South Asia, Bangladesh, India, Sri Lanka 


\section{ABBREVIATIONS}

$\begin{array}{lll}\text { ADB } & - & \text { Asian Development Bank } \\ \text { GDP } & - & \text { gross domestic product } \\ \text { GFCF } & - & \text { gross fixed capital formation } \\ \text { OLS } & - & \text { ordinary least squares } \\ \text { PPI } & - & \text { private participation in infrastructure } \\ \text { PPP } & - & \text { public-private partnership }\end{array}$





\section{INTRODUCTION}

1. South Asia has become the world's fastest-growing region according to the World Competitiveness Report (2016-2017) of the World Economic Forum. The report attributes the trend partly to upgraded infrastructure: especially, India, Bangladesh, and Sri Lanka show significant improvement in the quality of infrastructure (although from low levels). These countries are even projected to pick up speed or maintain growth (Table 1). Indeed, development of infrastructure is recognized as a critical driver of economic growth. For example, Calderón et al. (2011) estimate that a $7 \%-10 \%$ increase in power, transport, and telecommunication infrastructure can add $1 \%$ to a country's output. Evidence from developing Asian countries also shows significant reduction in poverty and income inequality from better road transport, electricity, and sanitation facilities (Asian Development Bank Institute 2009).

Table 1: South Asia Gross Domestic Product Growth-Long-Term Trends, Annual Variations

\begin{tabular}{lrrrrrrr}
\hline Country & $\mathbf{2 0 1 6}$ & $\mathbf{2 0 1 7}$ & $\mathbf{2 0 1 8}$ & $\mathbf{2 0 1 9}$ & $\mathbf{2 0 2 0}$ & $\mathbf{2 0 2 1}$ \\
\hline Bangladesh & 7.1 & 7.3 & 7.0 & 6.7 & 6.7 & 6.6 \\
\hline India & 7.1 & 6.6 & 7.3 & 7.6 & 7.6 & 7.7 \\
\hline Sri Lanka & 4.5 & 3.1 & 4.2 & 5.1 & 5.3 & 5.5 \\
\hline
\end{tabular}

Source: Data from 2016 to 2018 is from Asian Development Bank. 2018. Asian Development Outlook. Manila (April).

The projections for 2019 to 2021 are from FocusEconomics. 2018. Consensus Forecasts: East and South Asia (May).

2. However, despite having upgraded its infrastructure, South Asia lags most other regions and needs to do more. To sustain growth and deal with climate change, the region must invest almost $9 \%$ of its gross domestic product (GDP) on infrastructure development over the next one and a half decades (Figure 1). Of this, India alone will require some $\$ 260$ billion (Asian Development Bank [ADB] 2017a). Unless it takes urgent steps, South Asia's existing infrastructure could soon prove to be a roadblock in sustaining its growth momentum and addressing persisting poverty and inequality. This paper examines the determinants of infrastructure investment in the region with a view to making appropriate policy choices.

\footnotetext{
In this paper, South Asia refers to the group of six countries, namely: Bangladesh, Bhutan, India, Maldives, Nepal, and Sri Lanka, unless otherwise indicated.
} 
Figure 1: Infrastructure Investment Needs of Developing Asia, 2016-2030

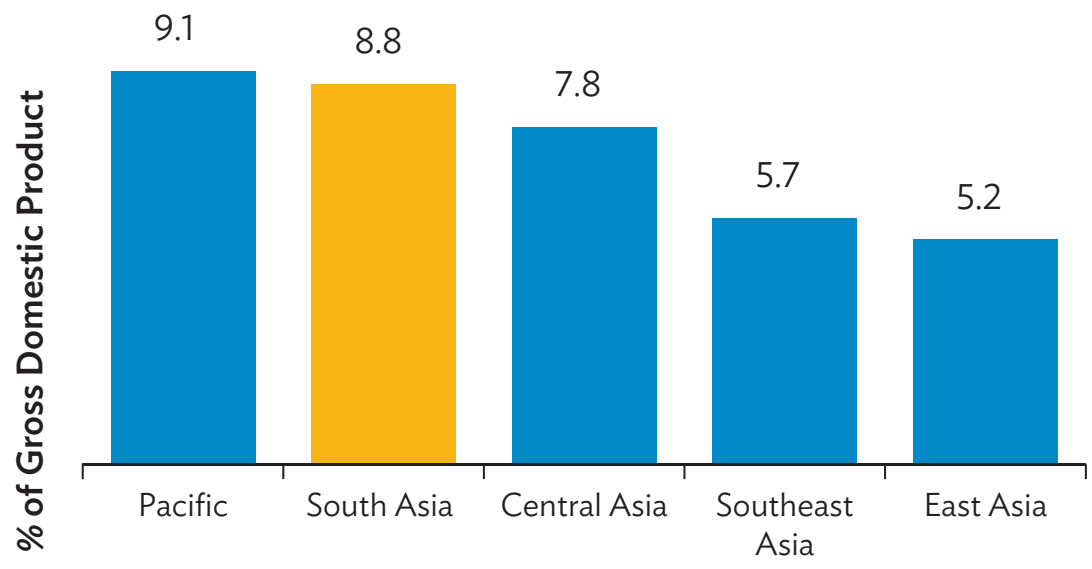

Subregions of Developing Asia

Note: In this chart, South Asia consists of Afghanistan, Bangladesh, Bhutan, India, Nepal, Maldives, Pakistan, and Sri Lanka. Source: Asian Development Bank (2017a).

\section{DEVELOPMENT OF INFRASTRUCTURE IN SOUTH ASIA: TRENDS AND QUALITY}

3. Transport and energy sectors account for a major share of infrastructure investments in developing Asian economies, followed by water and sanitation facilities (ADB 2017a). Within South Asia, countries differ widely in infrastructure service provision, and while the access has expanded the quality remains poor, as discussed below.

4. Over the last quarter of a century, South Asia made great strides in improving its physical infrastructure and related services. ${ }^{2}$ The overall quality of infrastructure taken together has improved, partly from innovations in and rapid evolution of the communication technology. Yet, starting from a weak base, South Asia still lags East Asia and the Pacific, and Latin America and the Caribbean in access to infrastructure services, especially in mobile cellular subscriptions and sanitation facilities; surpassing the performance only of sub-Saharan Africa (Figure 2).

2 Physical infrastructure is usually taken to represent various kinds of infrastructure, such as roads, railways, ports, and telecommunication networks; energy; and water and sanitation facilities. Such overall measure masks variations in the quality of individual types of infrastructure. Moreover, since measuring infrastructure is not easy, most studies focus only on one infrastructure sector. 
Figure 2: Access to Infrastructure Services, World Regions, 2014-2015

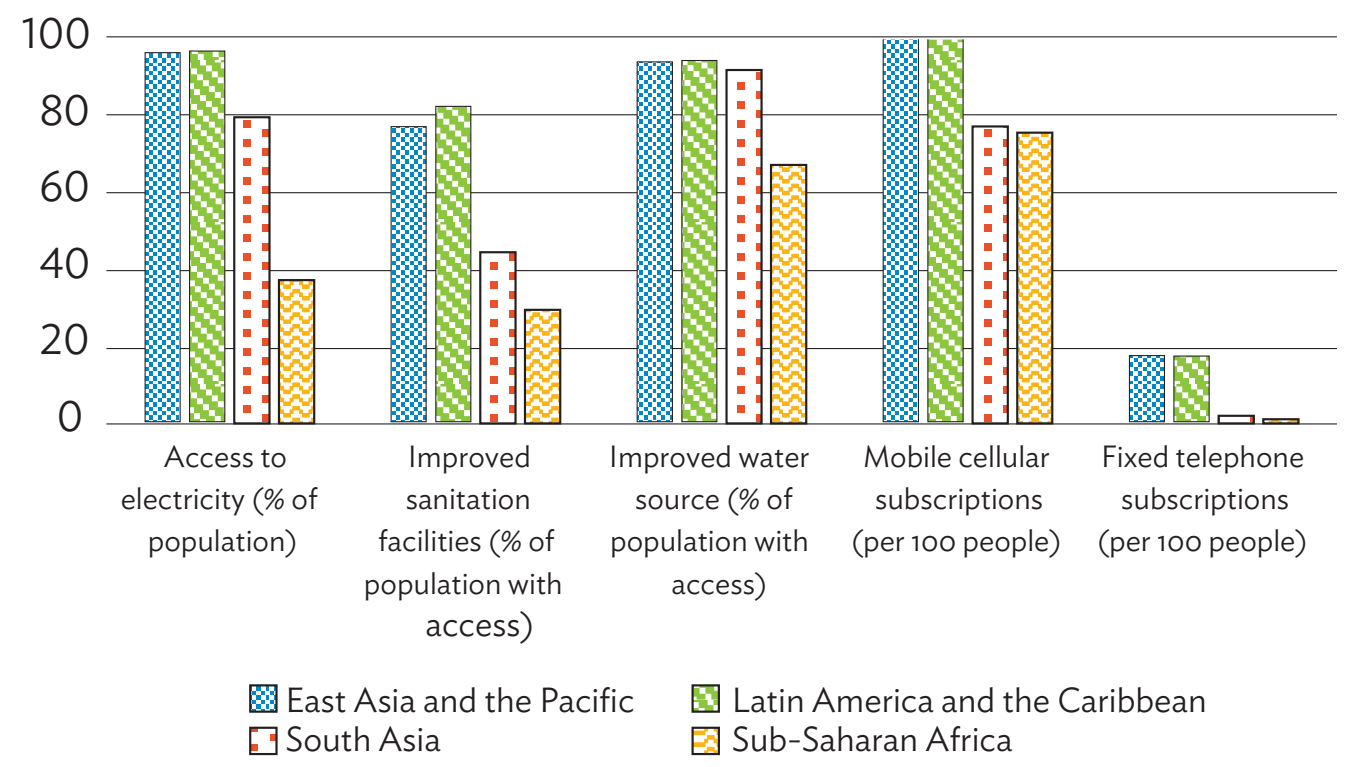

Source: World Bank World Development Indicators (last updated: 26 May 2017).

5. Large deficits prevail in transport and connectivity. Road density in South Asian countries, except in India is far below the world average of around 100 kilometers per 100 square kilometers of land area (Figure 3). Railway length per million people remains woefully inadequate as well in most countries of the region, significantly behind the averages for the Organisation for Economic Co-operation and Development and for the world.

6. In the international trading arena, among all world regions, South Asia in 2007 had the worst score on logistical performance in terms of trade and transport related infrastructure, which includes ports, railroads, roads, and information technology, among others. Over the decade since then, South Asia took a leap to rise high, moving ahead of sub-Saharan Africa and matching Latin America and the Caribbean (Figure 4). Most individual countries within South Asia made marked improvements as well (Figure 5). Yet much gap remains with other regions including the Middle East and North Africa. Despite substantial improvement, the quality of overall infrastructure in the region remains low with a score of barely 4.5 in comparison with the highest possible score of 7. More worrisome is the consistent deterioration over the last decade in the quality of roads due to lack of maintenance (Figure 6).

7. In access to electricity, some subregional countries lag those in Southeast Asia and East Asia. For example, just about $60 \%$ of the population in Bangladesh and $80 \%$ in India has access to electricity, even as almost the entire population is covered in Brunei Darussalam, Malaysia, the People's Republic of China, Singapore, Thailand, and Viet Nam (Figure 7). 
Figure 3: Railway and Road Length, Selected Asian Economies, 2011 and 2012

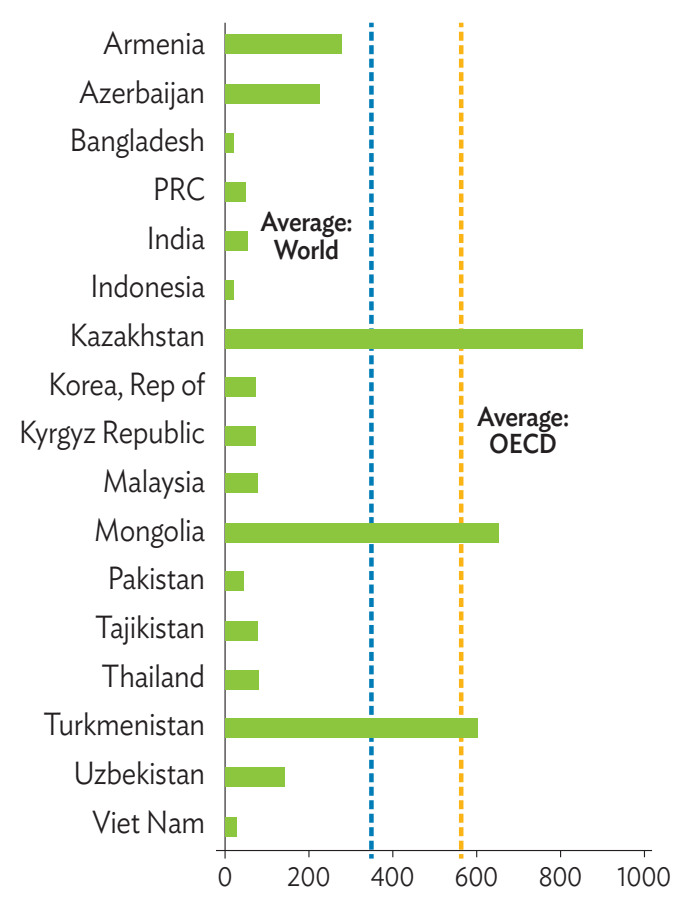

Railway length per 1 million people, 2012

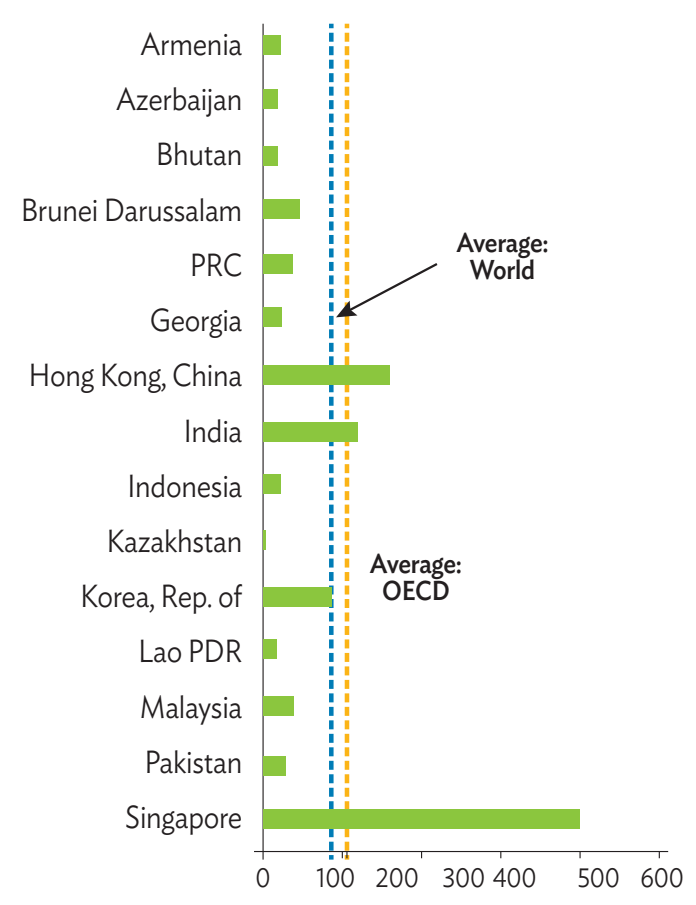

Road density (kilometer of road per 100 square kilometer of land area), 2011

Lao PDR = Lao People's Democratic Republic, OECD = Organisation for Economic, PRC = People's Republic of China, Co-operation and Development.

For railway length, world refers to the 83 countries in the World Development Indicators database with available data; for road density, world refers to the 92 countries in the World Development Indicators database with available data.

Note: Data refer to 2014 values.

Source: World Bank World Development Indicators online database (accessed April 2017).

8. Businesses suffer too. Power outages reported by local firms give an indication of the adequacy and stability of power supply. On average, firms in South Asia experience the most number of outages compared with other regions (Figure 8). In a typical month, a whopping 25.4 average number of power outages compared with only 2.2 in Latin America and 4.9 in East Asia and Pacific. More specifically, Allcott, Collard-Wexler, and O'Connell (2016) estimate that power shortages can reduce revenue and producer surplus of manufacturing firms in India by 5\%-10\%.

9. Indeed, firms in the region find poor quality and reliability of electricity supply to be a much bigger constraint than the availability of transport (Figure 9). While manufacturers in Bhutan do not seem to have severe power supply problems, other countries do. The shortage is particularly serious in Nepal with almost $70 \%$ of firms, and in Bangladesh over half the firms reporting it so. Frequent power disruptions interrupt production and significantly reduce productivity. They can also disrupt entire supply chains and lower the efficacy of longer-term investment planning. Transport problems in comparison affect less than 15\% of firms in Bangladesh, Bhutan, India, and Sri Lanka, whereas a third are affected in Nepal. 
Figure 4: Logistical Performance, World Regions, 2007 and 2016

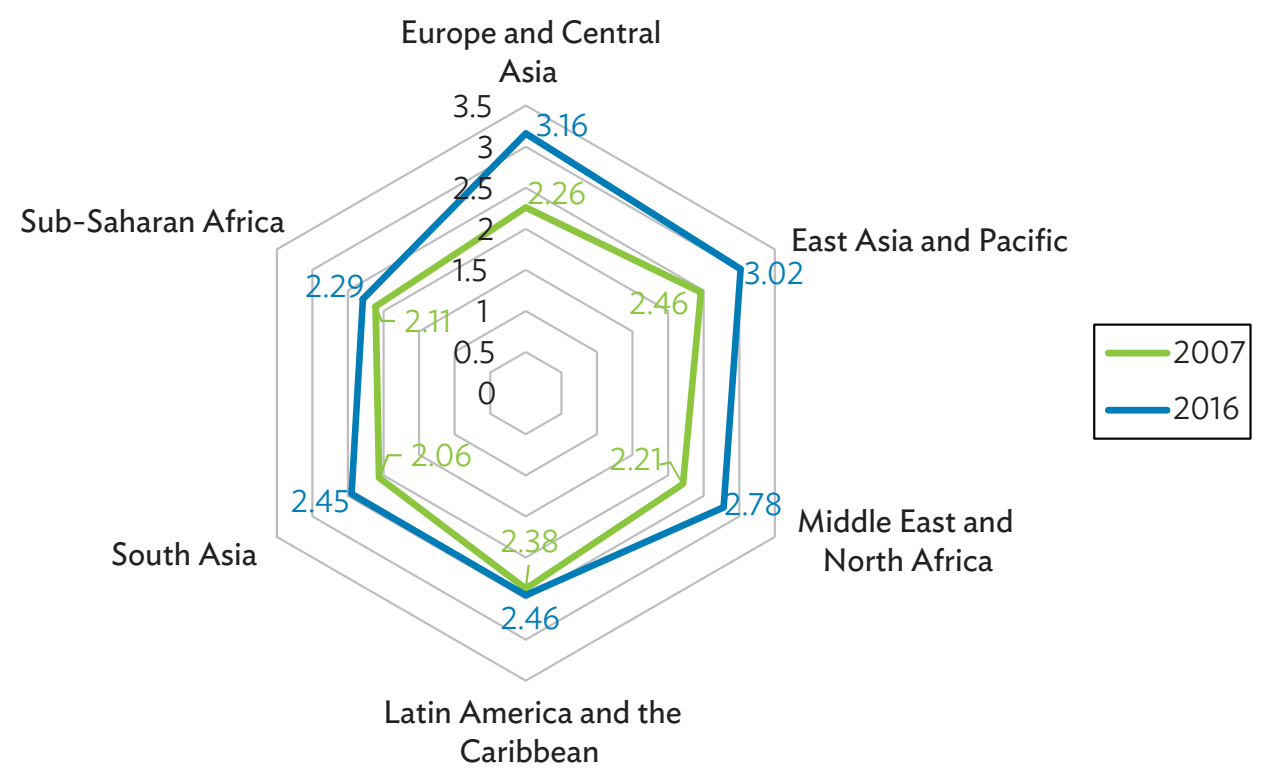

Notes: In this figure, South Asia consists of Afghanistan, Bangladesh, Bhutan, India, Sri Lanka, Maldives, Nepal, and Pakistan. Higher score indicates better quality.

Source: World Bank Logistics Performance Index 2016, downloaded 27 June 2017.

Figure 5: Logistical Performance, South Asian Countries, 2007 and 2016

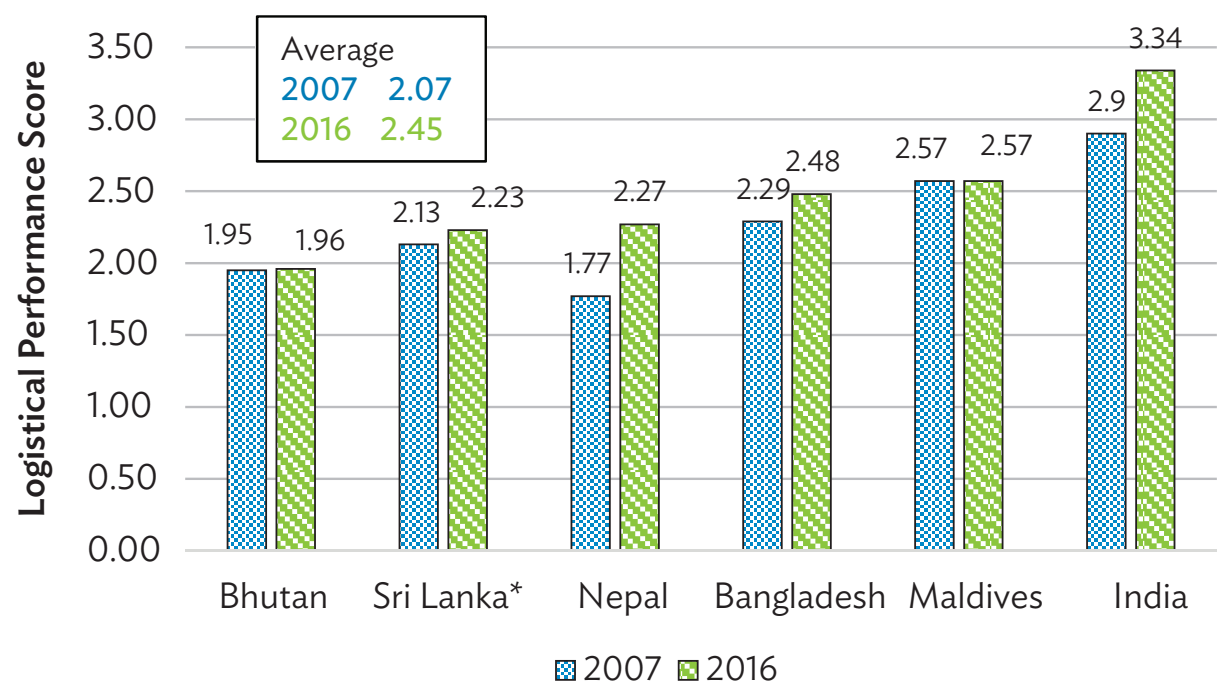

Notes: The trade and transport-related infrastructure includes ports, railroads, roads, information technology. The performance is measured in scores ranging from 0 (worst) to 7 (best).

* For Sri Lanka, the 2016 series refers to data for 2014. Higher score indicates better quality.

Source: World Bank Logistics Performance Index 2016, downloaded 27 June 2017. 
Figure 6: Trends in Infrastructure Quality, South Asia, 2007-2016

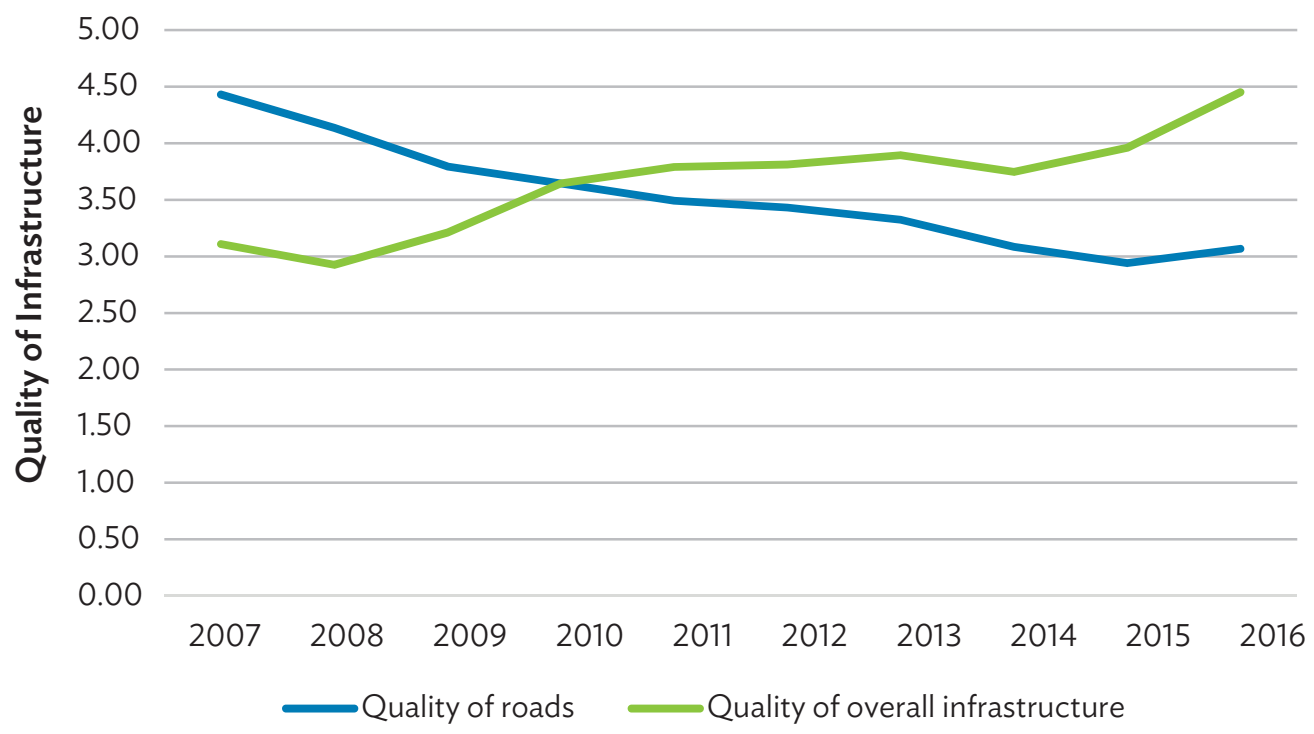

Note: Infrastructure and road quality is from 1-7, with 7 as the best.

Sources: Global Competitiveness Report 2016-2017; and CEIC Data Company.

Figure 7: Access to Electricity across Developing Asia, 2014

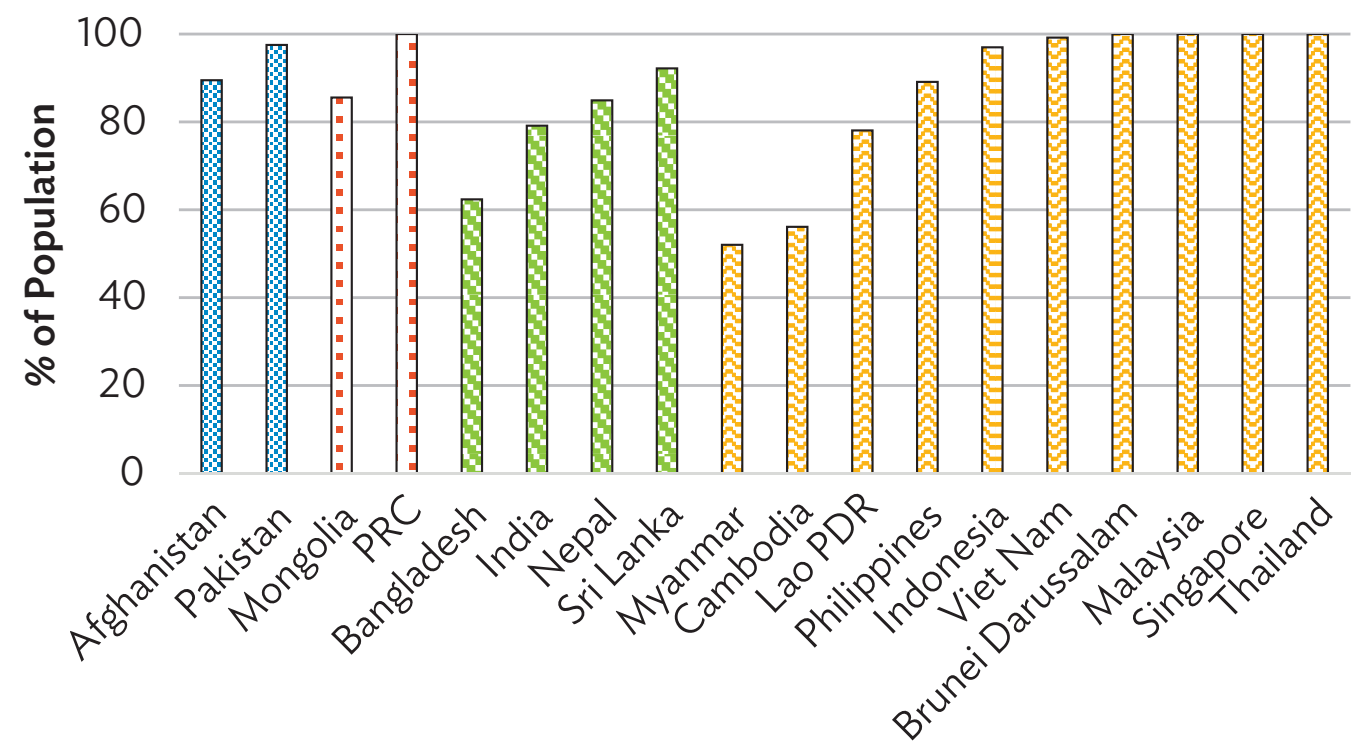

Lao PDR = Lao People's Democratic Republic, PRC = People's Republic of China.

Source: Data from database: World Development Indicators (last updated: 1 June 2017). 
Figure 8: Number of Electrical Outages Faced by Firms in a Typical Month, World Regions, 2017

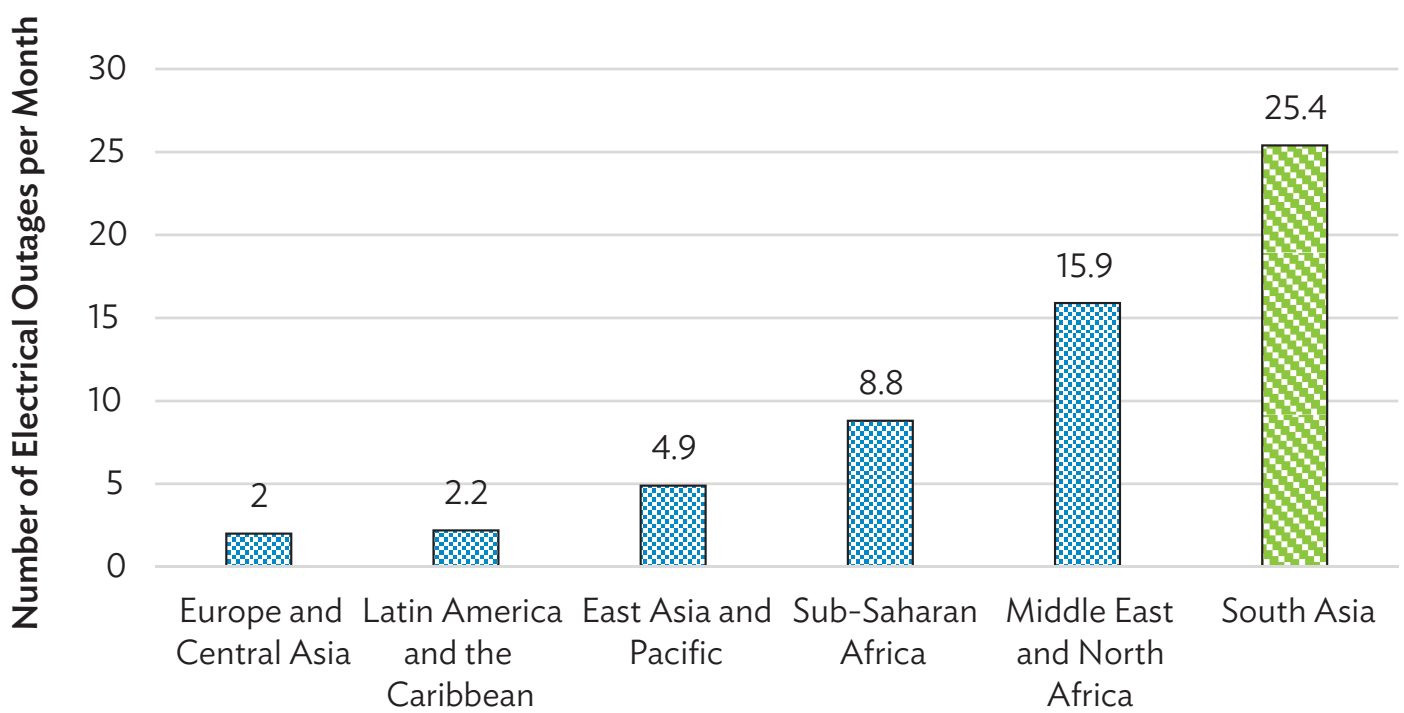

Source: Enterprise Survey, World Bank, accessed 4 September 2017.

Figure 9: Quality of Electricity Supply and Transportation for Firms in South Asian Countries, Latest Year

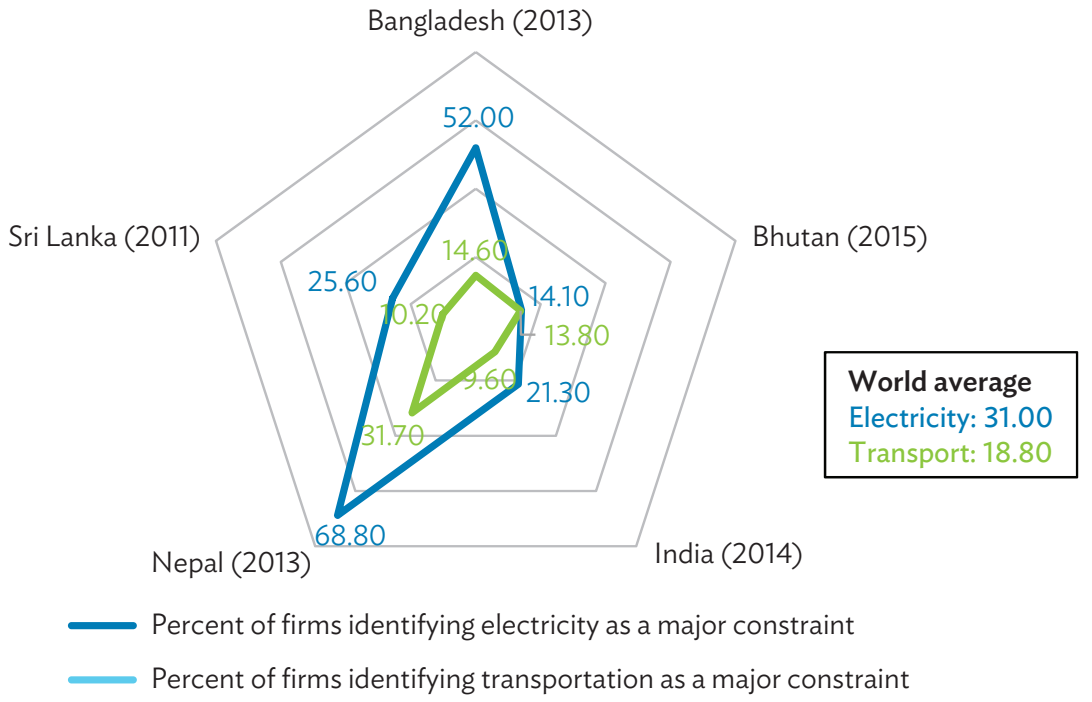

Note: Higher levels show poorer quality.

Source: Enterprise Survey, World Bank, accessed 4 September 2017. 
Figure 10: Quality of Water Supply and Shipping for Firms in South Asian Countries, Latest Year

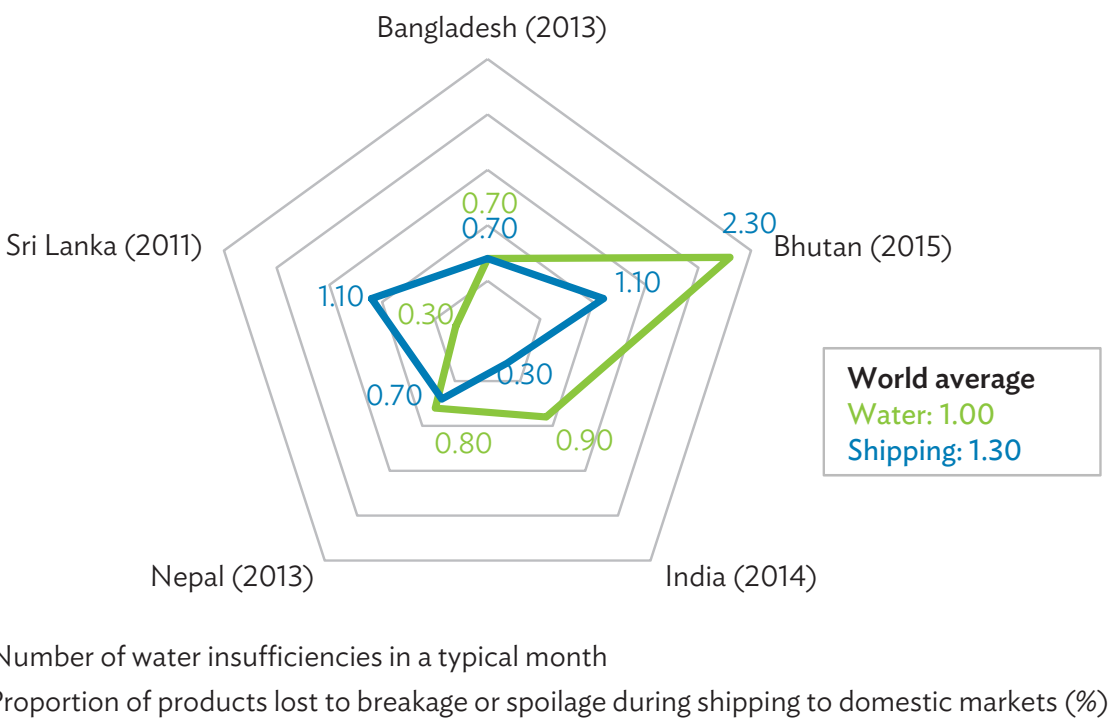

Note: Higher levels show poorer quality.

Source: World Bank Enterprise Survey.

10. Similar trends are observed for other types of infrastructure too in which much of South Asia has undergone a large expansion. With regard to the quality of water and shipping facilities, on an average, South Asian firms are better off than average firms worldwide (Figure 10). Except for Bhutanese firms, which score 2.3 on water shortages in a typical month, other South Asian countries have fewer water shortages than the world average score of 1.00. There is also minimal product loss to breakage and spoilage during shipping to domestic markets.

11. The quality of services, such as safe drinking water and sanitation, remains low. In 2015 , only $56 \%$ of South Asian residents used a safely managed drinking water service, that is, drinking water located on premises, available when needed, and free from contamination in comparison with $71 \%$ of the global population, with Latin America and the Caribbean at 65\%, and with Middle East and North Africa at 77\% (Figure 11). With only $48 \%$ of its population having access to at least basic sanitation services, that is, use of facilities not shared with other households, South Asia performs worse in this respect than all other world regions except sub-Saharan Africa (Figure 12). The related problem of open defecation especially stands out.

12. To sum up, despite decades of investment, the state of infrastructure in South Asia continues to remain wanting in comparison with global standards, deterring private investors. Insufficient and lowquality infrastructure services act as major impediments to business growth, thus affecting the rate of investment and capital formation. 
Figure 11: Access to Improved Water Sources, World Regions, 2015

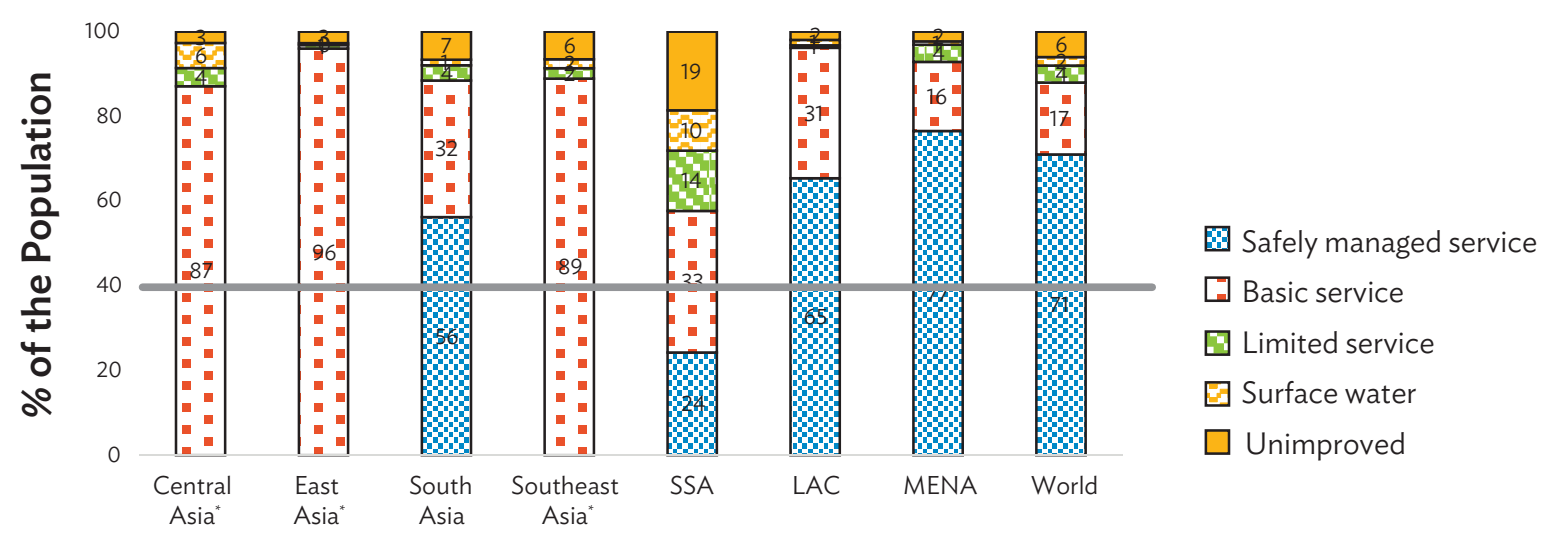

LAC = Latin America and the Caribbean, MENA = Middle East and North Africa, SSA = Sub-Saharan Africa.

*Insufficient data to estimate safely managed services.

Notes:

1. Improved sources include piped water, boreholes or tube wells, protected dug wells, protected springs, and packaged or delivered water.

2. Safely managed: Drinking water from an improved water source which is located on premises, available when needed, and free from fecal and priority chemical contamination.

3. Basic service: Drinking water from an improved source, provided collection time is not more than 30 minutes for a round-trip, including queuing.

4. Limited service: Drinking water from an improved source for which collection time exceeds 30 minutes for a round-trip, including queuing.

5. Surface water: Drinking water directly from a river, dam, lake, pond, stream, canal, or irrigation canal.

6. Unimproved: Drinking water from an unprotected dug well or unprotected spring.

Sources: World Health Organization/United Nations Children's Fund. 2017. Progress on Drinking Water, Sanitation and Hygiene: 2017 Update; and Sustainable Development Goal baseline (accessed 24 September 2017). 


\section{Figure 12: Access to Improved Sanitation Facilities, World Regions, 2015}

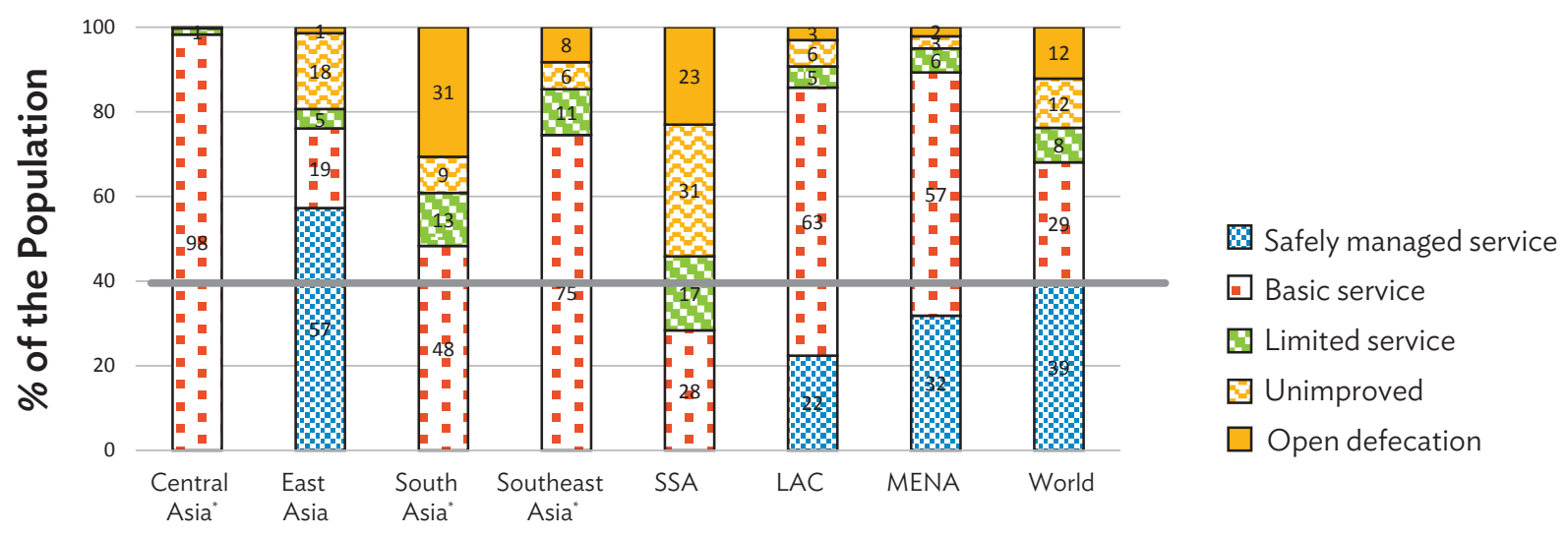

LAC = Latin America and the Caribbean, MENA = Middle East and North Africa, SSA = Sub-Saharan Africa.

* Insufficient data to estimate safely managed services.

Notes:

1. Improved facilities include flush/pour flush to piped sewer system, septic tanks, or pit latrines; ventilated improved pit latrines, composting toilets, or pit latrines with slabs.

2. Safely managed: Use of improved facilities which are not shared with other households and where excreta are safely disposed in situ or transported and treated off-site.

3. Basic service: Use of improved facilities which are not shared with other households.

4. Limited service: Use of improved facilities shared between two or more households.

5. Unimproved: Use of pit latrines without a slab or platform, hanging latrines, or bucket latrines.

6. Open defecation: Disposal of human feces in fields, forests, bushes, open bodies of water, beaches, and other open spaces, or with solid waste.

Sources: World Health Organization/United Nations Children's Fund. 2017. Progress on Drinking Water, Sanitation and Hygiene: 2017 Update; and Sustainable Development Goal baseline (accessed 24 September 2017). 


\section{PUBLIC AND PRIVATE SECTOR FINANCING}

13. Infrastructure services like roads and railways are "non-excludable" public goods in that people cannot be effectively excluded from its use even if they do not pay for it, and they are "non-rival" in nature since use by one person does not reduce its availability to others. For this type of infrastructure, markets fail to provide socially desirable levels of services. Infrastructure with network effects (e.g., mobile phone network or metro transport systems) or with monopolistic qualities (such as railways and power transmission) are also underprovided by the market. Beyond private benefits, some types of infrastructure offer additional-often unintended-benefits, known as externalities, which are not reflected in the price. For example, use of road transport leads to carbon emissions and causes air pollution, but road users do not pay for these costs. Such characteristics encourage private providers to raise prices and/or restrict supply below socially beneficial levels. Moreover, private infrastructure projects face general market risks from interest rate and inflation shocks, and political risks from policy change. For these reasons and to address social equity considerations, the public sector often ends up providing the services.

14. Indeed, the public sector finances over $60 \%$ of South Asia's infrastructure investment (ADB 2017a). Unlike other countries in the subregion, however, the private sector has played an increasingly important role in India: starting from 1960 and up until the late 1980s, private sector infrastructure investment was negligible. However, following the new wave of economic reforms it picked up a rapid upward trend starting in the early 1990s. Private sector investment soon overtook public investment (Figure 13).

Figure 13: Trends in Infrastructure Investment in India, 1960-2015

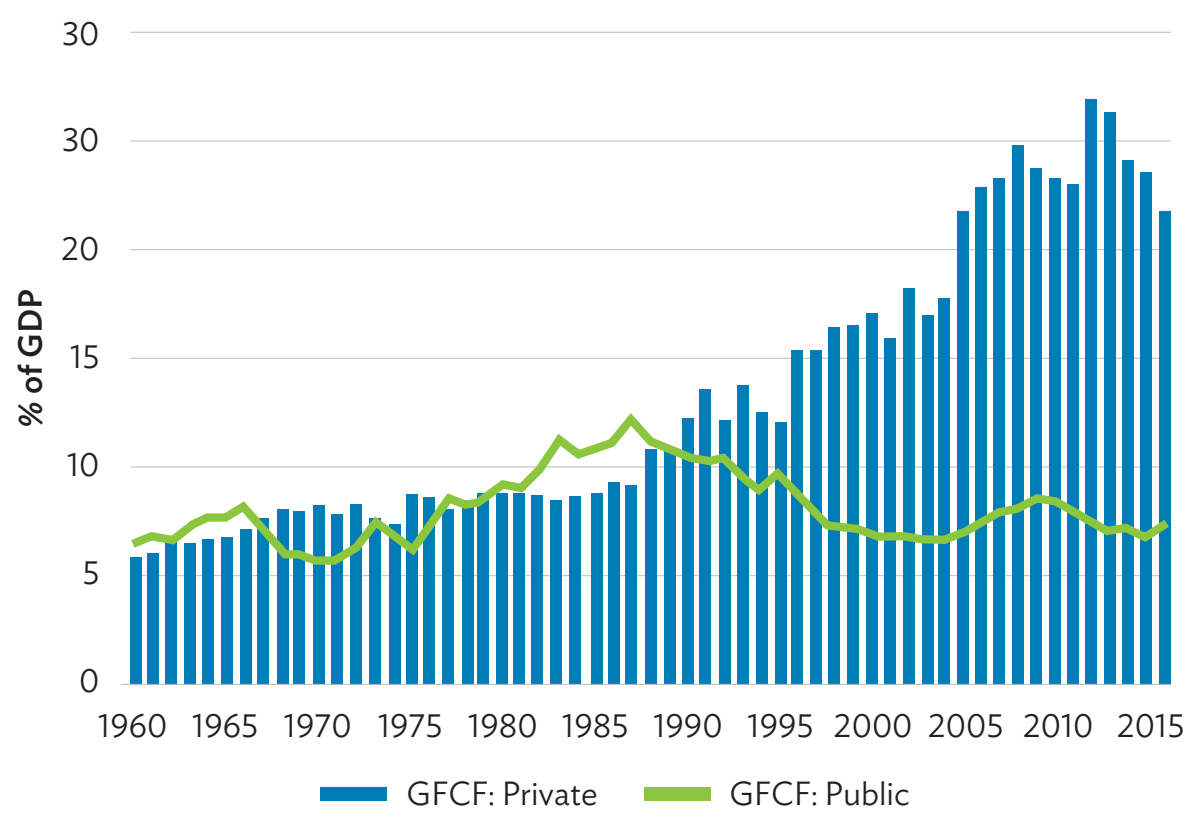

GDP = gross domestic product, GFCF = gross fixed capital formation .

Notes: GFCF includes financial and financial private corporations and the household sector. Public GFCF includes financial and financial public corporations and general government. Years pertain to fiscal years, ending March of each year.

Source: CEIC Data Company (accessed 6 November 2017). 
15. Formost governments, the fiscal position, which deteriorated following the 2008 global financial crisis, has not yet recovered to pre-crisis levels, further restricting budgetary capacity to finance (Figures 14 and 15). Faced with the twin challenge of fiscal consolidation and provision of adequate high-quality infrastructure, South Asia will need to mobilize more private finance. The large amount of infrastructure needed requires enhancement of public expenditure through more efficient use of budget spending, in addition to leveraging the private sector through, for example, expansion of public-private partnerships (PPP).

16. Public sector financing of infrastructure suffers from the low collection of user charges. The problem of tariffs, for example, for power and water, set at levels too low to cover operational and maintenance costs is widely known. Additionally, budgetary funds are used inefficiently. For example, while Sri Lanka is on the efficiency frontier in using its public health expenditure, other countries can attain their current levels of health outcomes by using less than their health budget: Bangladesh $94 \%$, Bhutan 88\%, India 78\%, Maldives 95\%, and Nepal 83\% (Lavado and Domingo 2015).

17. Globally, about 30\% of potential benefits from infrastructure investment is lost due to inefficiencies in investment planning and implementation (International Monetary Fund 2015). Closing this "efficiency gap" could yield twice the output "bang" for public investment expenditures. Low revenue collection and misuse of scarce fiscal resources can both be partly addressed by controlling corruption. Brook and Smith (2000), for example, find petty corruption surrounding metering at the interface with customers as a reason for low collection rates reported by gas, heating, and electricity companies in many developing countries, especially in South Asia.

Figure 14: Fiscal Balance, 2007 and 2016

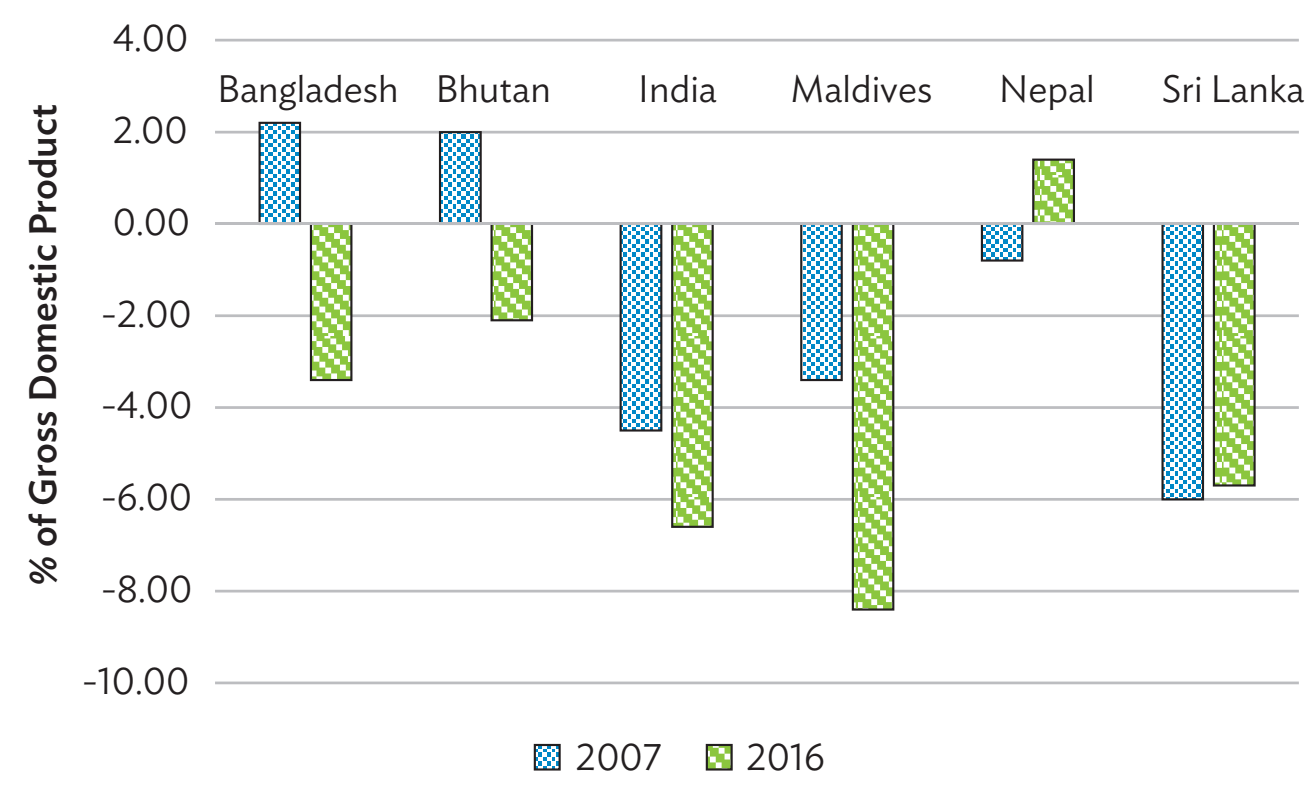

Source: Kose et al. (2017). 
Figure 15: General Government Debt, 2007 and 2016

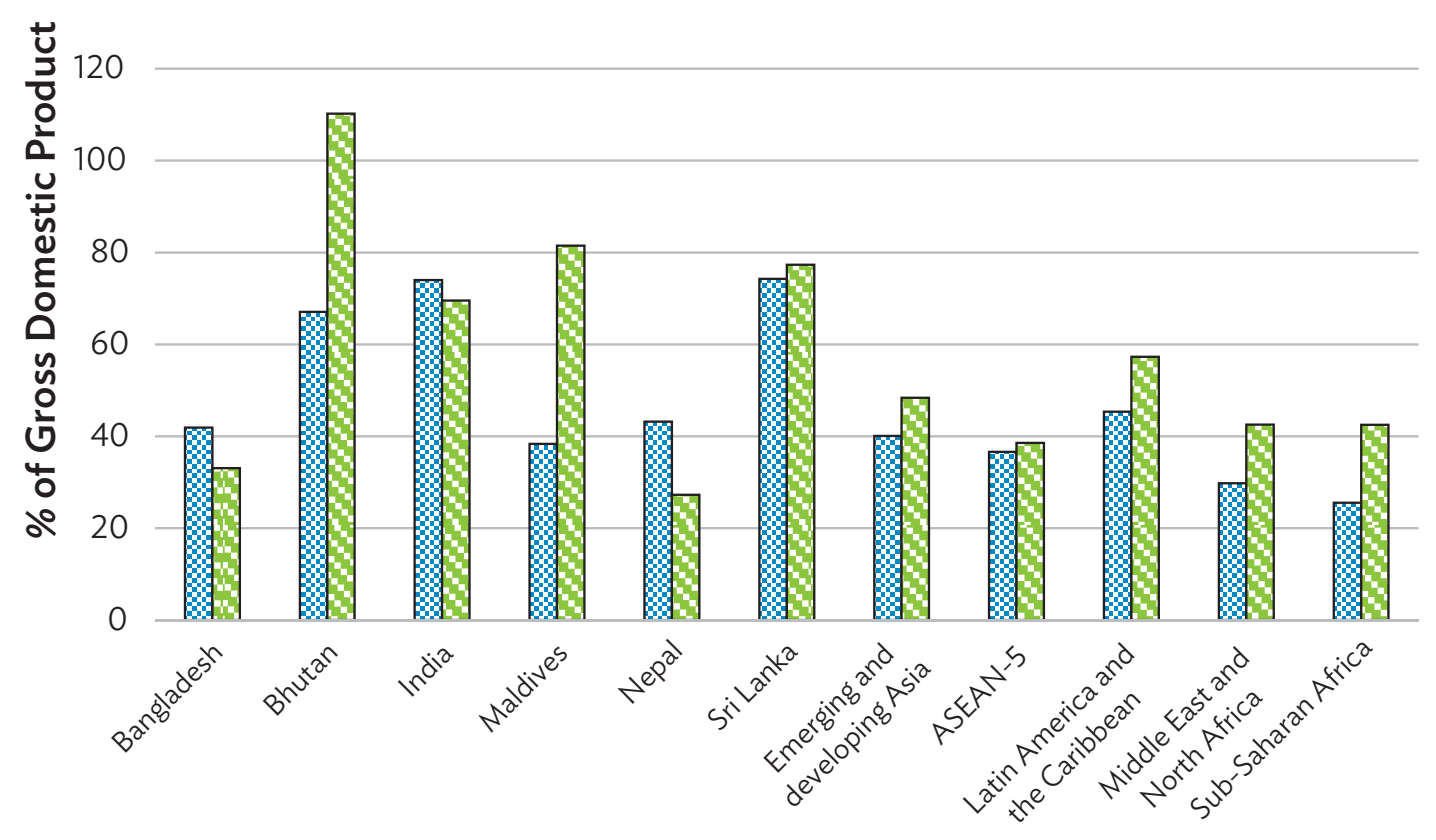

图 2007 圆 2016

ASEAN = Association of Southeast Asian Nations.

Notes:

1. Emerging and developing Asia: Bangladesh, Bhutan, Brunei Darussalam, Cambodia, the Federated States of Micronesia, Fiji, India, Indonesia, Kiribati, the Lao People's Democratic Republic, Malaysia, Maldives, the Marshall Islands, Mongolia, Myanmar, Nauru, Nepal, Palau, Papua New Guinea, the People's Republic of China, the Philippines, Samoa, Solomon Islands, Sri Lanka, Thailand, Timor-Leste, Tonga, Tuvalu, Vanuatu, and Viet Nam.

2. ASEAN-5: Indonesia, Malaysia, the Philippines, Thailand, and Viet Nam.

3. Latin America and the Caribbean: Antigua and Barbuda, Argentina, the Bahamas, Barbados, Belize, Bolivia, Brazil, Chile, Colombia, Costa Rica, Dominica, Dominican Republic, Ecuador, El Salvador, Grenada, Guatemala, Guyana, Haiti, Honduras, Jamaica, Mexico, Nicaragua, Panama, Paraguay, Peru, St. Kitts and Nevis, St. Lucia, St. Vincent and the Grenadines, Suriname, Trinidad and Tobago, Uruguay, and Venezuela.

4. Middle East and North Africa: Algeria, Bahrain, Djibouti, Egypt, Iran, Iraq, Jordan, Kuwait, Lebanon, Libya, Mauritania, Morocco, Oman, Qatar, Saudi Arabia, Sudan, Syria, Tunisia, United Arab Emirates, and Yemen.

5. Sub-Saharan Africa: Angola, Benin, Botswana, Burkina Faso, Burundi, Cabo Verde, Cameroon, Central African Republic, Chad, Comoros, Democratic Republic of the Congo, Republic of Congo, Côte d'Ivoire, Equatorial Guinea, Eritrea, Ethiopia, Gabon, The Gambia, Ghana, Guinea, Guinea-Bissau, Kenya, Lesotho, Liberia, Madagascar, Malawi, Mali, Mauritius, Mozambique, Namibia, Niger, Nigeria, Rwanda, São Tomé and Príncipe, Senegal, Seychelles, Sierra Leone, South Africa, South Sudan, Swaziland, Tanzania, Togo, Uganda, Zambia, and Zimbabwe.

Source: International Monetary Fund. 2017. World Economic Outlook Database. Washington, DC (April). 


\section{A. Corruption in Public Infrastructure Provision}

18. The largest procurement expense incurred by many governments is on infrastructure and utility provision - sectors which also face significant constraints on competition. Tanzi and Davoodi (1997) argue that weak institutional controls encourage larger public expenditure on highly visible infrastructure projects such as roads, airports, power plants, and ports that can be milked by corrupt politicians. This occurs at the cost of low operation and maintenance expenditures. As a result, not only does the quality of infrastructure suffer, it deteriorates faster as well. Based on the history of public utility markets, Troesken (2006) makes three observations: First, corruption is endemic to public utility industries; it exists across all regulatory and ownership regimes. Second, regime change in utility industries does not eliminate corruption; it only alters the type of corruption observed. Third, for any type of governance regime (e.g., state regulation or municipal ownership) corruption grows increasingly severe over time and, at some point, becomes politically untenable.

19. Corrupt practices pervade publicly provided infrastructure services from the planning stage to service delivery, for example, construction of electricity and transport facilities, public works contracts, and power and water utilities. Broadly, corruption in an infrastructure sector can be grouped along two dimensions: state capture and administrative corruption. State capture is the influence in the formulation of laws, regulations, and government policies while administrative corruption is the influence on how the established rules are implemented. Knowledge of such activities would be helpful for the project administrator in allocating scarce resources to the phases in the project cycle that might be least susceptible to corruption.

20. Table 2 lists potential areas of the two dimensions in the project cycles of transport and energy infrastructure. State capture may take the form of large-scale bribery through illicit agreements between management of public utilities and large private sector industrial customers. This may lead to heavily discounted rates, and insignificant collections from the largest consumers. High levels of administrative corruption can increase project implementation costs, such as during road construction or electricity distribution. It is common for small users and informal sector outfits, for example, to illegally connect to the electricity grid without a meter. Thus, not all of electricity distributed is purchased resulting in a lower level of paid consumption, the difference capturing theft and diversion. Additionally, small-scale bribery may be perpetrated between low-level employees like electricity meter readers and residential customers. Individually, the costs are immaterial, but in the aggregate the financial implications could be substantial. Since this type of corruption interfaces with the public, it contributes to a culture and perception of corruption and undermines the ability of the public entity to function properly. Ultimately, this may be more damaging to the institution than the financial loss.

Table 2: State Capture and Administrative Corruption in the Project Cycle

\begin{tabular}{|c|c|c|}
\hline Corruption & Transport & Energy \\
\hline State capture & $\begin{array}{l}\text { Planning (location) } \\
\text { Design (favor bidder) }\end{array}$ & $\begin{array}{l}\text { Planning (under/overestimate demand) } \\
\text { Regulation (favorable energy policy) }\end{array}$ \\
\hline Administrative & $\begin{array}{l}\text { Construction (cut corners) } \\
\text { Monitoring (bribe engineer) } \\
\text { Procurement (collusion) }\end{array}$ & $\begin{array}{l}\text { Distribution (bribe meter readers, side agreements with industrial } \\
\text { consumers) } \\
\text { Inter trading activity (favorable transactions among energy } \\
\text { entities/private firms and government) }\end{array}$ \\
\hline
\end{tabular}

Source: Authors' compilation. 
21. The complexity of PPP contracts and their long-term nature may limit participation in tenders, thus favoring anticompetitive agreements. Adopting a sole-source process can save the government time and money, and may alert it to an unrealized opportunity for PPP. However, it can also encourage corruption and forego the benefits of competitive bidding (ADB 2008). Worldwide data from development aid-financed infrastructure projects reveal that the average number of bidders may be as low as only 2-6 firms in electricity, water and sanitation, and roads (Auriol and Søreide 2017). Such small numbers of bidders make it difficult for governments to exclude a supplier due to lack of integrity. This anticompetitive effect facilitates collusion between suppliers. In some cases, only one bidder submits a proposal. Though this undermines competition, technically, attracting only one bid should not be a problem provided due diligence is carried out. Debarment mechanisms should be designed to deter both collusion and corruption. Unless these persistent problems are resolved, the objective of bringing the private sector on board to finance infrastructure may remain unfulfilled.

\section{B. Leveraging the Private Sector}

22. Bankable infrastructure projects are difficult to design due to their complexity. They require bulky and front-loaded capital expenditure; extensive, advanced planning; and long lead times to generate cash flows to meet the project's financial obligations. In the case of financing by syndicates, proper financial structure needs to be in place to deal with legal issues (Box 1). On the other hand, PPP projects are completed on time and within budget compared with the public sector (Jordan-Tank 2017). The PPP industry-including construction firms, equipment suppliers, and institutional equity fundsmakes joint investments in areas such as transport, municipal utility, renewables, hospitals, and schools.

\section{Box 1: Building a Pipeline of Bankable Private Sector Projects}

A limited pipeline of bankable projects hinders greater private investment in infrastructure. For example, a country's development strategy may include creating a transport and economic corridor. Based on this goal, a set of projects can be identified - such as specific highways, railway corridors, and power generation and transmission lines - that require development or expansion.

To become bankable, projects should be formulated based on appropriate processes and due diligence from the prefeasibility study stage onward, including economic and financial analysis of project costs and benefits, project structuring (for example, debt and equity requirements), specification of the procurement modality to be used (for example, build-operate-transfer or build-own-operate-transfer), detailed project report preparation, environmental clearances, and approvals for land acquisition.

Building a robust pipeline of bankable projects requires a regulatory and institutional framework that supports

(i) specific types of procurement contract;

(ii) project identification and structuring appropriate for the specified procurement;

(iii) inclusion of a dispute resolution mechanism;

(iv) streamlined processes for environmental and other regulatory permits for construction and operation;

(v) clearly defined costs and service levels;

(vi) well-defined bid parameters (for example, minimum viability gap requirements provided by the government); and

(vii) establishment of an independent tariff-setting authority.

Source: Asian Development Bank (2017a). 
23. During the last quarter of the century, South Asia accounted for the largest share at almost $40 \%$ of PPP investment among all the subregions of developing Asia (Figure 16). Most of it went into energy infrastructure, followed by information and communication technology and transport. However, as a percentage of GDP, South Asia's investment fell slightly short of Southeast Asia's, although the two have been moving together in unison (Figure 17). Evidently, private infrastructure investment boom in the region tapered off following the Asian financial crisis in 1997 and the 2007 global financial crisis. This may reflect in part that post-crisis investments became riskier, or that the world economic landscape weakened, or maybe accessing credit/finance became more difficult.

24. Based on a survey in Bangladesh, India, Indonesia, Kazakhstan, Papua New Guinea, the People's Republic of China, the Philippines, Thailand, and Viet Nam, a new ADB report found that energy generation is one of the most successful sectors in developing PPP frameworks, with thermal and renewable power generation being the dominant technologies (ADB 2017b). The water sector is also a major area for PPP investment in this group of countries. While social sector PPPs have made

Figure 16: Public-Private Partnership Investment in Developing Asia, 1991-2015

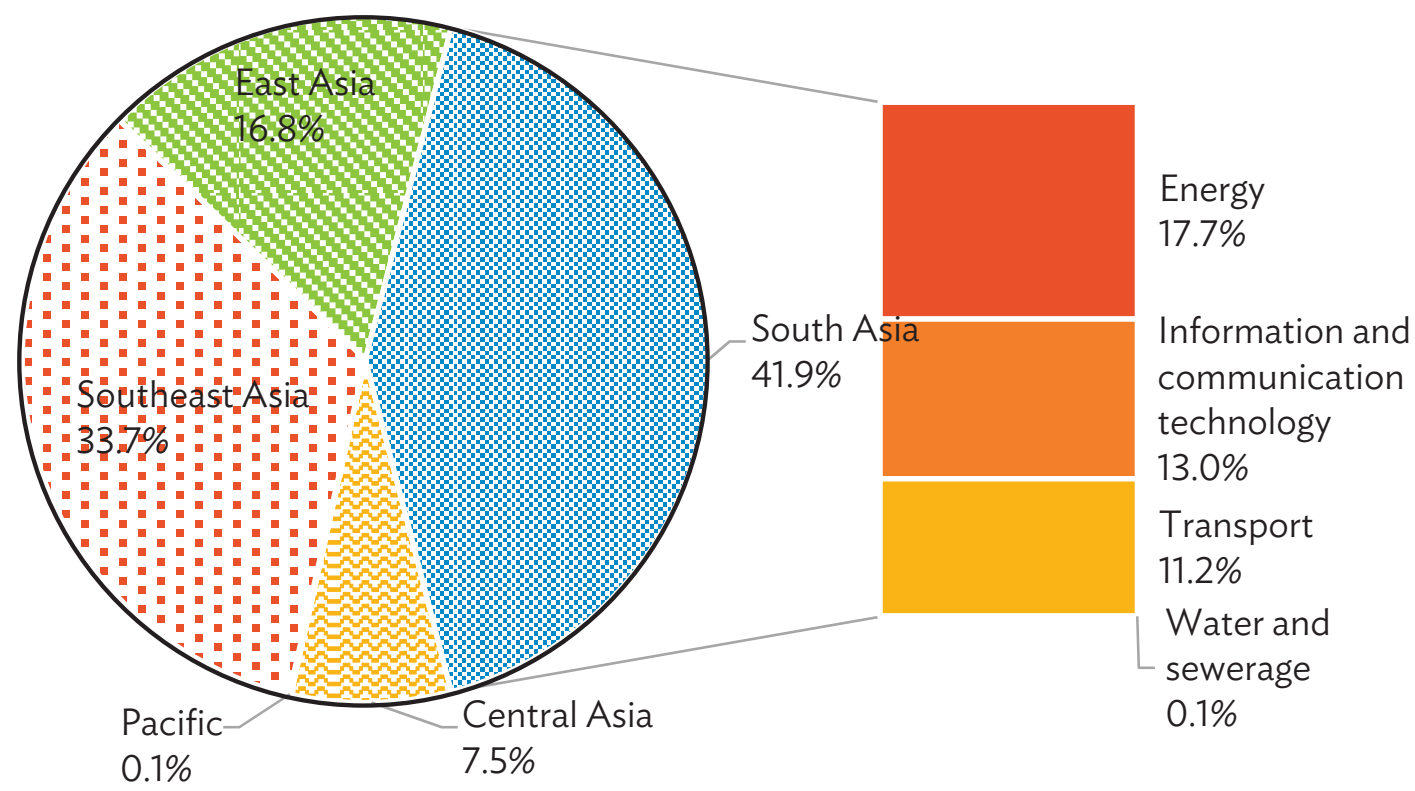

Notes:

1. Developing Asia comprises the 45 members of the Asian Development Bank with available data.

2. Central Asia includes Afghanistan, Armenia, Azerbaijan, Georgia, Kazakhstan, the Kyrgyz Republic, Pakistan, Tajikistan, Turkmenistan, and Uzbekistan.

3. East Asia includes Mongolia and the People's Republic of China.

4. South Asia includes Bangladesh, Bhutan, India, Maldives, Nepal, and Sri Lanka.

5. Southeast Asia includes Cambodia, Indonesia, the Lao People's Democratic Republic, Malaysia, Myanmar, the Philippines, Thailand, and Viet Nam.

6. The Pacific includes Fiji, the Federated States of Micronesia, Papua New Guinea, Samoa, Solomon Islands, Timor-Leste, Tonga, and Vanuatu.

7. Investment amounts refer to total investment commitments entered into by the project entity at the beginning of the project (at contract signature of financial closure), not the planned or executed annual investment.

Source: World Bank Private Participation in Infrastructure database (accessed 21 November 2017). 


\section{Figure 17: Public-Private Partnership Investment in Developing Asia, by Subregion} (\% of gross domestic product)

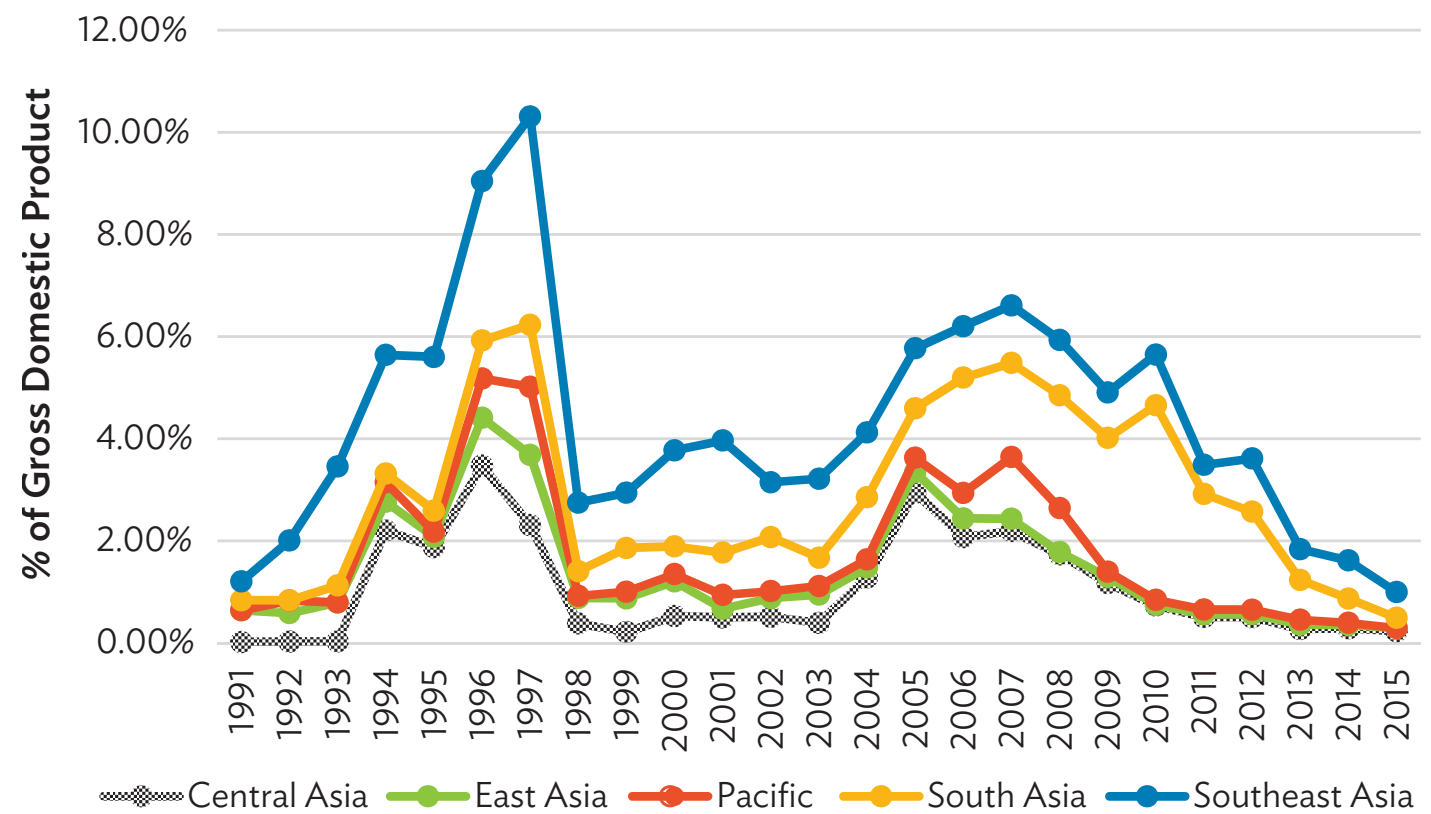

ASEAN $=$ Association of Southeast Asian Nations

Notes:

1. Emerging and developing Asia: Bangladesh, Bhutan, Brunei Darussalam, Cambodia, the Federated States of Micronesia, Fiji, India, Indonesia, Kiribati, the Lao People's Democratic Republic, Malaysia, Maldives, the Marshall Islands, Mongolia, Myanmar, Nauru, Nepal, Palau, Papua New Guinea, the People's Republic of China, the Philippines, Samoa, Solomon Islands, Sri Lanka, Thailand, Timor-Leste, Tonga, Tuvalu, Vanuatu, and Viet Nam.

2. ASEAN-5: Indonesia, Malaysia, the Philippines, Thailand, and Viet Nam.

3. Latin America and the Caribbean: Antigua and Barbuda, Argentina, the Bahamas, Barbados, Belize, Bolivia, Brazil, Chile, Colombia, Costa Rica, Dominica, Dominican Republic, Ecuador, El Salvador, Grenada, Guatemala, Guyana, Haiti, Honduras, Jamaica, Mexico, Nicaragua, Panama, Paraguay, Peru, St. Kitts and Nevis, St. Lucia, St. Vincent and the Grenadines, Suriname, Trinidad and Tobago, Uruguay, and Venezuela.

4. Middle East and North Africa: Algeria, Bahrain, Djibouti, Egypt, Iran, Iraq, Jordan, Kuwait, Lebanon, Libya, Mauritania, Morocco, Oman, Qatar, Saudi Arabia, Sudan, Syria, Tunisia, United Arab Emirates, and Yemen.

5. Sub-Saharan Africa: Angola, Benin, Botswana, Burkina Faso, Burundi, Cabo Verde, Cameroon, Central African Republic, Chad, Comoros, Democratic Republic of the Congo, Republic of Congo, Côte d'Ivoire, Equatorial Guinea, Eritrea, Ethiopia, Gabon, The Gambia, Ghana, Guinea, Guinea-Bissau, Kenya, Lesotho, Liberia, Madagascar, Malawi, Mali, Mauritius, Mozambique, Namibia, Niger, Nigeria, Rwanda, São Tomé and Príncipe, Senegal, Seychelles, Sierra Leone, South Africa, South Sudan, Swaziland, Tanzania, Togo, Uganda, Zambia, and Zimbabwe.

Source: International Monetary Fund. 2017. World Economic Outlook Database. Washington, DC (April). 
slow progress overall, India is the most successful and has implemented several PPPs in health care. India is also one of the most developed financial markets in the group (ADB 2017b). It can provide longer-tenor loans (above 10 years) in local currency to support infrastructure, and it offers a wide array of financing options including project bond financing. However, much is needed for further PPP development, including enhanced development of financial facilities, further diversification of the investor base, managing the risk of fluctuating traffic in transport projects, developing a credible pipeline of PPP projects, and expanding toward sectors beyond energy (ADB 2017c).

25. Moreover, the volumes of listed and unlisted instruments of project finance and PPPs in Asia remain small in relation to its investment needs and well below the global average (Inderst 2016). To generate a pipeline of bankable PPPs, it is necessary to attract private investors and regulate PPPs. This requires legal, regulatory, and institutional reforms such as PPP laws, streamlined procurement and bidding processes, and dispute resolution mechanisms. With appropriate regulatory and institutional frameworks, most Asian economies will be in a strong position to carry out public-private deals for improving infrastructure (Box 2).

26. Despite the improvements in PPP readiness, South Asia is not private sector-friendly compared with other regions (Table 3). Especially, at the subnational level, not all areas are equally efficient. Data for states in India, e.g., show wide variations in the amount of time a firm may have to spend in major cities before it can go from one step to the next (Figure 18). Although it takes between about 30 days and 40 days to start a business anywhere in the country, registering a property could take just 24 days in the city of Jaipur to as many as 18 weeks in Bhubaneshwar. In a small city like Guwahati, a contract could be enforced in 600 days, whereas in the commercial center Mumbai, a firm may have to wait for almost 4 years on average to have its contract enforced.

\section{Box 2: Readiness for Public-Private Partnerships}

The capacity of governments to finance infrastructure is limited, and there is a strong commitment to privately financed infrastructure and the important contribution they may bring. The Asia-Pacific Infrascope, a benchmarking index designed by the Economist Intelligence Unit, uses 19 indicators to measure a country's ability to mobilize private investment in infrastructure through public-private partnerships (PPPs). The index is intended to assess progress in the environment for PPPs in infrastructure and to encourage change.

The latest index relates to 2014. All countries included in the previous Asia-Pacific Infrascope for 2011 improved their ratings in 2014. They made significant progress to improve PPP readiness through better regulatory framework governing project selection, improvement in the capacity of public sector agencies, the design and management of bid processes, and wider implementation of mechanisms such as alternative dispute resolution to improve certainty for private sector bidders. Japan, Bangladesh, Papua New Guinea, and the Philippines were the top improvers in political will. These countries were also the most improved in operational maturity, emphasizing the important connection between political will, improved PPP regulatory frameworks, and the number of transactions implemented.

The 2014 Asia-Pacific Infrascope shows significant improvement in transaction flows over the previous 3 years. Many emerging economies made large overall gains and displayed greater convergence of scores in 2014 than in 2011. The data suggests a positive correlation between overall score, and regulatory and institutional frameworks. This is consistent with empirical evidence that early development of robust regulatory and market institutions is an important starting point for overall PPP market effectiveness.

Source: Economist Intelligence Unit (2014). 
27. Even if corrupt practices are curtailed, the objective of Basel III to prevent another financial crisis makes it unfriendly to infrastructure investment. This makes it difficult for banks to finance long-term projects. While bank loans dominate private infrastructure finance in South Asia, much scope exists for the development of capital markets, a greater supply of financially viable projects, and improvements in the legal and regulatory environment. For example, although banks have been the driver of infrastructure financing in India, however, weighed down by bad loans and weak profitability, they are reaching their exposure limits in infrastructure lending.

28. A shift to other instruments such as bonds, market securities, and foreign investment is imminent and necessary (Romero-Torres, Bhatia, and Sural 2017). Higher capital requirements and maturity mismatch for long-term projects mean a greater role for bond financing to complement banks. In general, as countries move to higher-income levels, meeting infrastructure challenge will require development of capital markets, insurance companies, and pension funds, which could share the infrastructure risk. Apart from finance, technical expertise and good management practices from the private sector can also improve infrastructure efficiency. Designing policies to improve this situation will require a better understanding of key factors in South Asia that keep private players at bay.

Table 3: Cost of Doing Business, World Regions, 2017

\begin{tabular}{lcccc}
\hline & \multicolumn{3}{c}{ Number of days needed to perform a task } \\
\cline { 2 - 5 } Region & Start a Business & $\begin{array}{c}\text { Enforce } \\
\text { Contracts }\end{array}$ & $\begin{array}{c}\text { Get Electricity } \\
\text { Resolve Insolvency } \\
\text { (number of years) }\end{array}$ \\
\hline East Asia and the Pacific & 22.8 & 565.7 & 71.6 & 2.6 \\
\hline Eastern Europe and Central Asia & 10.1 & 489.9 & 113.7 & 2.3 \\
\hline Latin America and the Caribbean & 31.8 & 767.1 & 66.0 & 2.9 \\
\hline Middle East and North Africa & 19.0 & 638.5 & 81.4 & 3.0 \\
\hline OECD high income & 8.5 & 577.8 & 79.1 & 1.7 \\
\hline South Asia & 15.5 & $1,101.6$ & 136.4 & 115.3 \\
\hline Sub-Saharan Africa & 24.1 & 656.8 & & 2.6 \\
\hline
\end{tabular}

OECD = Organisation for Economic Co-operation and Development.

Note: South Asia consists of Afghanistan, Bangladesh, Bhutan, India, Sri Lanka, Maldives, Nepal, and Pakistan.

Source: World Bank. 2018. Doing Business. Washington, DC. 
Figure 18: Number of Days for Doing Business, States in India, 2017

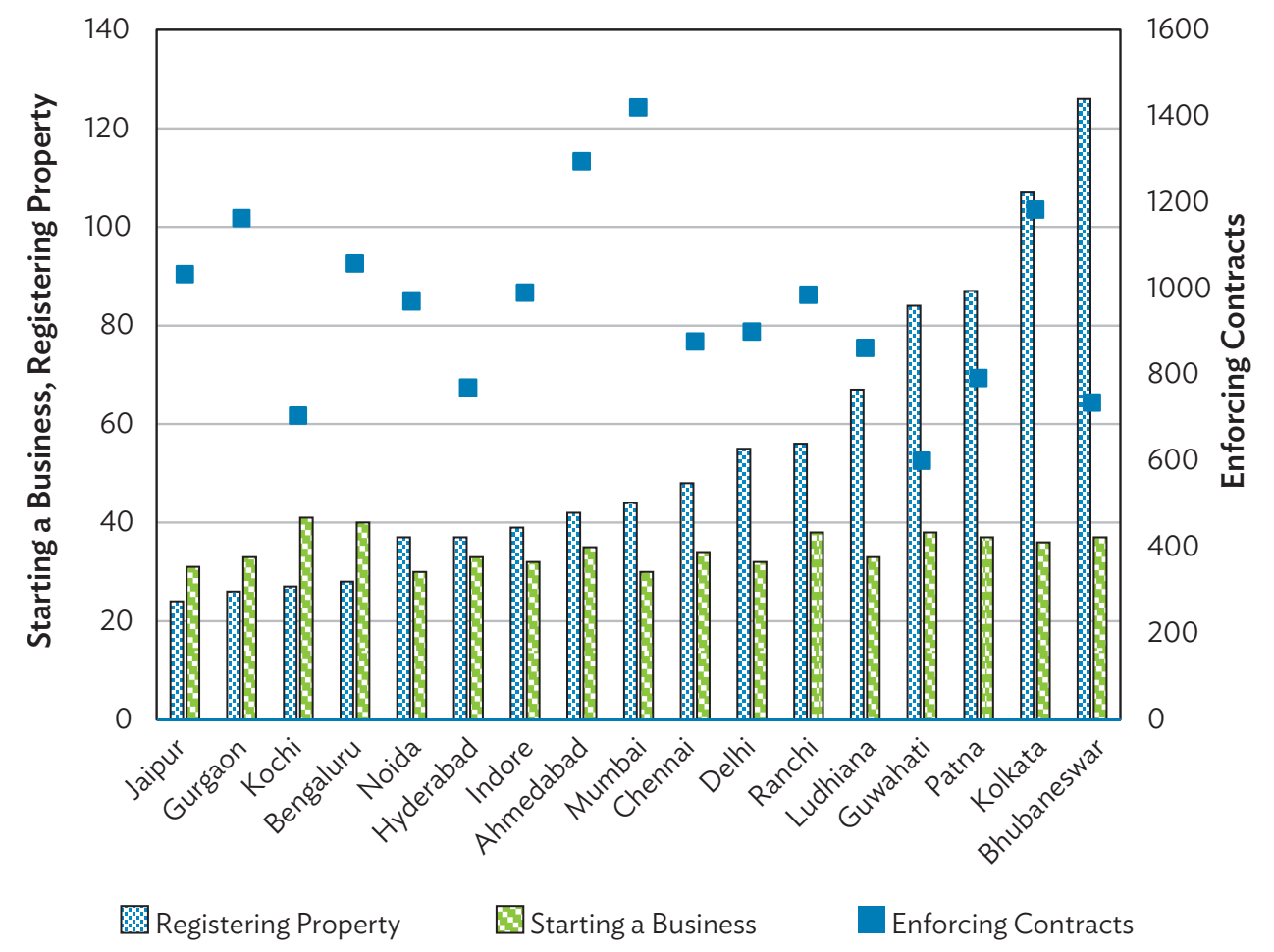

Source: World Bank. 2018. Doing Business. Washington, DC. 


\section{DRIVERS OF INFRASTRUCTURE INVESTMENT}

29. This section aims to identify the macroeconomic determinants of investment in infrastructure in three large South Asian countries; namely, India, Bangladesh, and Sri Lanka, for which consistent data is available for a long period viz 1996-2016. We use panel data analysis, controlling for country-level economic, institutional, and policy variables, to estimate the following ordinary least squares (OLS) regression:

$$
\begin{aligned}
& \text { Infra }_{i t}=\propto+\beta_{1} \text { GDPpc }_{i t-1}+\beta_{2} \text { Pop }_{i t}+\beta_{3} \text { Growth }_{i t-1}+\beta_{4} \text { Credit }_{i t}+\beta_{5} \text { Inflation }_{i t-1}+ \\
& \beta_{6} \text { Openness }_{i t-1}+\beta_{7} \text { Debt }_{i t-1}+\beta_{8} X_{i t j}+\varepsilon_{i t}
\end{aligned}
$$

where Infra $_{i t}$ refers to total investment in infrastructure for country $i$ in year $t$. Country-fixed effects and year dummies capture changes over time that are common across countries. To address the problem of endogeneity in our specification, we assume that investment is affected by events of the previous year. $G D P_{i t-1}$ is the lagged GDP per capita in current United States dollars. Growth it-1 $_{\text {and }}$ is the lagged growth rate of GDP. Both are expected to positively affect infrastructure investment. Pop $p_{i t}$ is the

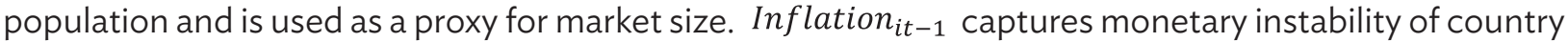
$i$ in year $t-1$ and is expected to have a negative impact. Openness $s_{i t-1}$ is an indicator of the openness of the country calculated as the sum of exports and imports over GDP. Debt $t_{i t-1}$ is debt as a share of GDP.

30. Credit it is the domestic credit provided to the private sector as a percentage of GDP. It captures the availability of financial resources for the private sector. $X_{i t j}$ are institutional variables for country $i$ at time $t$ such as freedom from corruption, government effectiveness, and rule of law from the World Bank's World Governance Indicators. We also use the quality of government indicator provided by the International Country Risk Guide as an institutional variable. It refers to the average value of corruption, law and order, and bureaucracy quality scores of country $i$ at time $t$. Higher values indicate higher quality of government. (See the Appendix for further details on the explanatory variables.)

\section{A. Total Public and Private Investment}

31. Table 4 shows the results of the panel estimation using OLS fixed effects. For this specification, we use as a measure of infrastructure investment the sum of public sector investment ${ }^{3}$ from the International Monetary Fund Investment and Capital Stock Dataset and infrastructure investments by the private sector from World Bank's Private Participation in Infrastructure (PPI) database. In the absence of cross country data on infrastructure investment, the main strength of using these measures is the availability of a long-time series (ADB 2017a). However, some caveats must be noted. First, not all components of public sector gross fixed capital formation (GFCF) may be related to infrastructure. For instance, it may include investment in machinery and equipment, which could overstate infrastructure investment. Also, public sector GFCF does not capture investments made by state-owned-enterprises, which could underestimate public infrastructure investment. Likewise, PPI data could underestimate total private infrastructure investment since it only includes projects with publicly available information. Moreover, PPI data are merely financial commitments and not actual investments.

3 This refers to the general government capital stock constructed based on general government investment flows GFCF. 
32. We find that variables associated with economic development, access to finance, and institutional variables, such as control of corruption and regulatory quality, are relevant channels for the determination of total infrastructure investment in India, Bangladesh, and Sri Lanka, taken together (column 4, Table 4).

33. Corruption undermines development by distorting the rule of law and weakening the institutional foundation for growth. Further, availability of infrastructure depends not just on the amounts spent on construction and maintenance, but it is influenced also by the efficiency of such spending. Corruption in project selection and government procurement practices is likely to weaken the link between public spending and infrastructure capital (Pritchett 2000, Keefer and Knack 2007). Private investors may face corruption during the implementation of projects, such as during construction of power plants or in electricity distribution. Private sector efficiency could fall if investors face difficulties in setting up and running a business operation, whereas effective regulations that limit corruption would mean higher efficiency. In line with the above arguments, we find that better control of corruption positively impacts infrastructure investment (column 4, Table 4). Likewise, improvements in regulatory quality and business freedom that indicates a better environment for business operation attract investment (columns 3, 4, and 5; Table 4).

34. Our results show that, once we control for institutional and governance quality, access to finance positively impacts investment in infrastructure (columns 3-4, Table 4). This finding is supported by the observation that the quality of infrastructure moves together with the share of construction in total credit (Figure 19). Further, countries with higher public debt as a share of GDP in the previous year are more likely to be in a weak budgetary position today and are, therefore, less likely to attract investment (columns 1, 2, and 5; Table 4). El-Ashram (2017), however, advises against such a myopic view of debt sustainability risks. El-Ashram shows how to avoid biases against good self-financing projects that pay

\section{Figure 19: Better Quality of Infrastructure Associated with Larger Share of Credit} for Construction vis-à-vis Other Areas

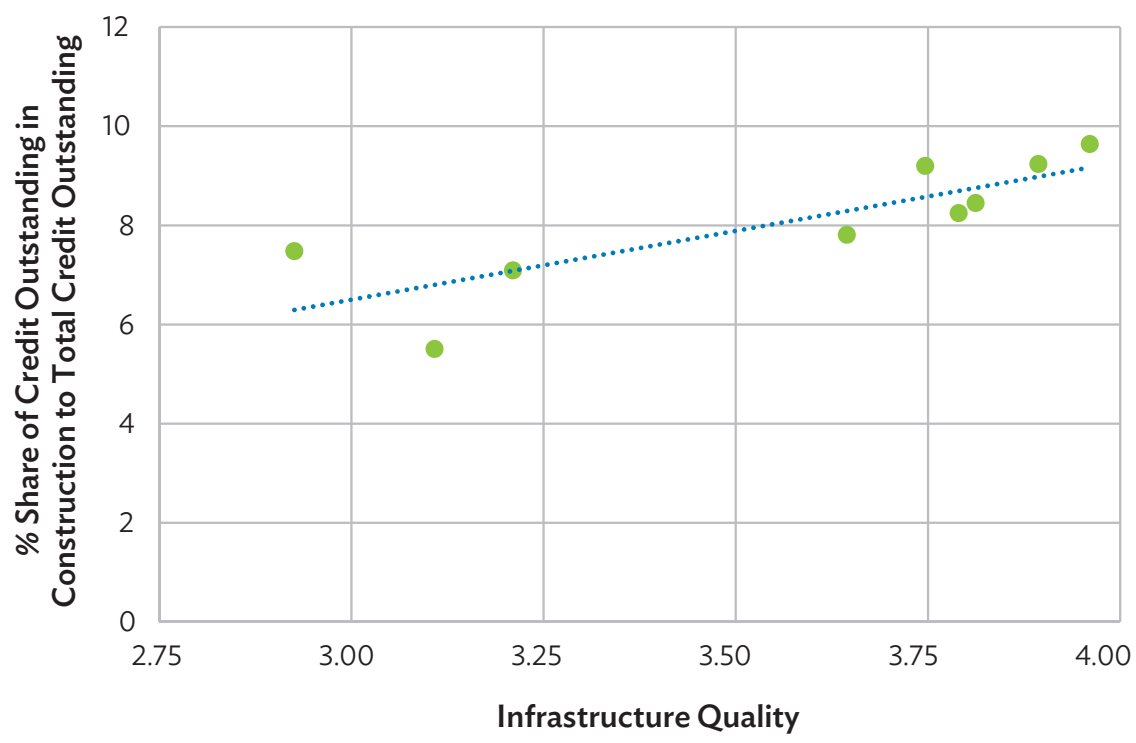

Note: Infrastructure quality is from 1 to 7 , with 7 as the best.

Sources: Global Competitiveness Report 2016-2017; and CEIC Data Company. 
Table 4: Panel Estimation Results, Ordinary Least Squares Fixed Effects

\begin{tabular}{|c|c|c|c|c|c|c|}
\hline \multirow[b]{2}{*}{ Variable } & \multicolumn{6}{|c|}{ Infrastructure Investment } \\
\hline & (1) & (2) & (3) & (4) & (5) & (6) \\
\hline \multirow{2}{*}{ GDP per capita $_{(\mathrm{t}-1)}$} & $2.000^{* * *}$ & $2.004^{* * *}$ & $1.827^{* *}$ & $2.298^{* * *}$ & $1.780^{* * *}$ & $1.685^{* * *}$ \\
\hline & $(<0.001)$ & $(<0.001)$ & $(0.0199)$ & $(0.00268)$ & $(0.00269)$ & $(0.00246)$ \\
\hline \multirow[t]{2}{*}{ Population } & -2.037 & -2.108 & -0.389 & -4.422 & -0.228 & -1.184 \\
\hline & $(0.252)$ & $(0.258)$ & $(0.901)$ & $(0.179)$ & $(0.922)$ & $(0.589)$ \\
\hline \multirow[t]{2}{*}{ GDP growth $_{(\mathrm{t}-1)}$} & -0.0347 & -0.0335 & 0.0761 & 0.0822 & 0.0263 & 0.0258 \\
\hline & $(0.559)$ & $(0.580)$ & $(0.364)$ & $(0.283)$ & $(0.730)$ & $(0.709)$ \\
\hline \multirow[t]{2}{*}{ Domestic credit to private sector } & $-0.186^{*}$ & $-0.181^{*}$ & 0.247 & $0.675^{*}$ & -0.208 & -0.126 \\
\hline & $(0.0582)$ & $(0.0817)$ & $(0.510)$ & $(0.0818)$ & $(0.184)$ & $(0.375)$ \\
\hline \multirow{2}{*}{ Inflation $_{(\mathrm{t}-1)}$} & -0.0390 & -0.0431 & -0.0192 & -0.0337 & -0.0411 & -0.0748 \\
\hline & $(0.480)$ & $(0.491)$ & $(0.760)$ & $(0.560)$ & $(0.517)$ & $(0.192)$ \\
\hline \multirow{2}{*}{ Trade openness $_{(\mathrm{t}-1)}$} & 0.225 & 0.237 & -0.109 & -0.0759 & 0.123 & $0.389^{* *}$ \\
\hline & $(0.193)$ & $(0.221)$ & $(0.640)$ & $(0.721)$ & $(0.524)$ & $(0.0369)$ \\
\hline \multirow{2}{*}{$\operatorname{Debt}_{(t-1)}$} & $-1.016^{* * *}$ & $-1.040^{* * *}$ & -0.708 & -0.498 & $-0.830^{* *}$ & $-0.763^{*}$ \\
\hline & $(0.00318)$ & $(0.00714)$ & $(0.177)$ & $(0.300)$ & $(0.0391)$ & $(0.0547)$ \\
\hline \multirow[t]{2}{*}{ Control of corruption } & & & 0.386 & $0.761^{* * *}$ & & \\
\hline & & & $(0.137)$ & $(0.00876)$ & & \\
\hline \multirow[t]{2}{*}{ Government effectiveness } & & & -0.0895 & 0.108 & & \\
\hline & & & $(0.723)$ & $(0.655)$ & & \\
\hline \multirow[t]{2}{*}{ Regulatory quality } & & & $0.564^{* *}$ & $0.819^{* * *}$ & & \\
\hline & & & $(0.0118)$ & $(0.000661)$ & & \\
\hline \multirow[t]{2}{*}{ Quality of government } & & -0.0742 & & & & \\
\hline & & $(0.886)$ & & & & \\
\hline \multirow[t]{2}{*}{ Rule of law } & & & & $-0.704^{* *}$ & & \\
\hline & & & & $(0.0131)$ & & \\
\hline \multirow[t]{2}{*}{ Index of business freedom } & & & & & $0.00684^{* *}$ & 0.00315 \\
\hline & & & & & $(0.0388)$ & $(0.311)$ \\
\hline \multirow[t]{2}{*}{ Index of investment freedom } & & & & & 0.00115 & 0.000676 \\
\hline & & & & & $(0.595)$ & $(0.719)$ \\
\hline \multirow[t]{2}{*}{ Index of property rights protection } & & & & & & $-0.0179^{* * *}$ \\
\hline & & & & & & $(0.00235)$ \\
\hline \multirow[t]{2}{*}{ Index of government integrity } & & & & & & -0.00419 \\
\hline & & & & & & $(0.297)$ \\
\hline \multirow[t]{2}{*}{ Constant } & $51.34^{*}$ & $52.73^{*}$ & 20.45 & $90.37^{*}$ & 18.28 & 36.75 \\
\hline & $(0.0812)$ & $(0.0921)$ & (0.689) & $(0.0997)$ & $(0.633)$ & $(0.311)$ \\
\hline Observations & 60 & 60 & 42 & 42 & 53 & 53 \\
\hline R-squared & 0.932 & 0.932 & 0.938 & 0.950 & 0.938 & 0.956 \\
\hline Number of countries & 3 & 3 & 3 & 3 & 3 & 3 \\
\hline \multicolumn{7}{|l|}{$\mathrm{GDP}=$ gross domestic product. } \\
\hline \multicolumn{7}{|c|}{$\begin{array}{l}\text { Notes: } \\
\text { 1. All continuous variables are log-transformed. } \\
\text { 2. p-values in parentheses. }{ }^{* *}, * * * \text { denote significance at the } 1 \%, 5 \% \text {, and } 10 \% \text { level, respectively. } \\
\text { 3. Infrastructure investment refers to the sum of public capital stock and private participation in infrastructure investment. } \\
\text { For a detailed description of the variables used in the regression, refer to the Appendix. }\end{array}$} \\
\hline
\end{tabular}

Source: Asian Development Bank estimates based on various data sources. Please refer to the Appendix for a full list of data sources. 
off over long horizons through user fees without discouraging the private sector. Since well-planned and executed user charges generate a revenue stream, e.g., in the energy sector, some projects can cover their cost of financing. Projects such as investments in disaster-resilient infrastructure may even generate fiscal cost savings.

\section{B. Private Investment by Sector}

35. We now focus only on private financing of infrastructure using data from the PPI database. Our results show that private investment is higher in more advanced economies, in larger markets, and in countries with better access to finance (columns 1-2, Table 5). Decisions of the private sector to enter the South Asian market for infrastructure overall are influenced by dynamic factors such as how fast or slow the country is making progress and the availability of credit from local commercial banks that attracts private investors.

36. Regulatory quality is also a significant determinant of PPI (columns 3-4, Table 5). Likewise, greater openness to trade, a measure of a country's receptiveness to foreign investment, attracts more private sector participation in infrastructure projects (column 3-4, Table 5). According to Moszoro et al. (2015), infrastructure investment decisions are influenced by many factors. However, the existence of a stable and predictable environment is vital in providing confidence to domestic and foreign investors.

37. Next, we consider the determinants of private investment by sector. The presence of private players is likely to depend on sector-specific features, such as favorable returns through recovery of costs from user charges and predictable revenue streams. Telecommunication, power, and railways often attract private finance, but not roads despite potentially high returns (Berg et al. 2015). This finding is supported by ADB (2017a) which notes that water and sanitation, and transport infrastructure are rarely financed privately. The result is poor road networks. The main reason is that road use cannot be directly charged except for toll roads, and most of the roads cannot be toll roads for reasons of equity and practicality (most roads are local or provincial roads that cannot be tolled). It can be indirectly financed using public money collected as cess on consumption of fuel, which is a proxy for the use of road network. Other possible reasons why private investors stay away from roads could be decreasing returns to scale, long gestation period, uncertainty in road usage, low cost recovery through user charges, and weak governance and noncompetitive practices. More developed capital markets and better institutions are known to encourage higher private participation, especially in telecommunication and transport. Effective regulation and competition policies are also significant factors that are likely to influence private infrastructure financing.

38. For the following sector-level analysis, we use the World Bank's PPI database. Although this database classifies infrastructure projects into four sectors; namely, energy, telecommunication, transport, and water and sanitation, our analysis is restricted to the first three only due to lack of a complete and consistent data series for water and sanitation. ${ }^{4}$

\footnotetext{
$4 \quad$ Energy comprises electricity generation, transmission, and distribution; and natural gas transmission and distribution. Telecommunication includes fixed or mobile local telephony, domestic long-distance telephony, and international long-distance telephony. Transport covers airport runways and terminals; railway fixed assets, freight, and intercity and local passenger service; toll roads, bridges, highways, and tunnels; and seaport channel dredging and terminals. Water and sanitation consists of potable water generation and distribution, as well as sewage collection and treatment. We specify private sector investment in infrastructure in logarithms and moving averages (of 7 years for transport projects, 9 years for energy projects, 5 years for telecommunication projects, and 15 years for water projects) to consider that data on investment are discrete observations of commitments (Moszoro et al., 2015). For example, for transport investment, 7-year moving average at time $t$ is derived as follows:

$$
\text { transport_ma7 }_{t}=\left(\text { transport }_{m a 7_{t-3}}+\text { transport }_{m a 7_{t-2}}+\text { transport }_{m a 7_{t-1}}+\text { transport }_{m a 7_{t}}+\text { transport }_{m a 7_{t+1}}\right.
$$$$
\left.+ \text { transport }_{m a 7_{t+2}}+\text { transport }_{m a 7_{t+3}}\right) / 7
$$ 
Table 5: Panel Estimation Results: Private Participation in Infrastructure

\begin{tabular}{|c|c|c|c|c|c|c|}
\hline \multirow[b]{2}{*}{ Variable } & \multicolumn{6}{|c|}{ Private Participation in Infrastructure } \\
\hline & (1) & (2) & (3) & (4) & (5) & (6) \\
\hline \multirow{2}{*}{ GDP per capita ${ }_{(t-1)}$} & -0.395 & -0.457 & $3.387^{* *}$ & $3.700^{* *}$ & -0.655 & 0.205 \\
\hline & $(0.760)$ & $(0.725)$ & $(0.0403)$ & $(0.0325)$ & $(0.697)$ & $(0.910)$ \\
\hline \multirow[t]{2}{*}{ Population } & $9.574^{*}$ & $10.74^{*}$ & 3.054 & 0.379 & 9.276 & 5.440 \\
\hline & $(0.0723)$ & $(0.0538)$ & $(0.647)$ & $(0.960)$ & $(0.187)$ & $(0.475)$ \\
\hline \multirow{2}{*}{ GDP growth $_{(\mathrm{t}-1)}$} & $0.393^{* *}$ & $0.373^{* *}$ & 0.132 & 0.136 & $0.409^{*}$ & $0.496^{* *}$ \\
\hline & $(0.0291)$ & $(0.0402)$ & $(0.459)$ & $(0.450)$ & $(0.0791)$ & $(0.0433)$ \\
\hline \multirow[t]{2}{*}{ Domestic credit to private sector } & $0.862^{* * *}$ & $0.787^{* *}$ & $-1.599^{*}$ & -1.315 & 0.562 & 0.382 \\
\hline & $(0.00385)$ & $(0.0117)$ & $(0.0516)$ & $(0.146)$ & $(0.228)$ & $(0.439)$ \\
\hline \multirow{2}{*}{ Inflation $_{(\mathrm{t}-1)}$} & -0.00753 & 0.0587 & 0.0720 & 0.0624 & 0.0171 & 0.0657 \\
\hline & $(0.963)$ & $(0.750)$ & $(0.592)$ & $(0.646)$ & $(0.928)$ & $(0.739)$ \\
\hline \multirow{2}{*}{ Trade $_{(\mathrm{t}-1)}$} & -0.494 & -0.688 & $0.910^{*}$ & $0.932^{*}$ & -0.138 & -0.0251 \\
\hline & $(0.333)$ & $(0.227)$ & $(0.0742)$ & $(0.0707)$ & $(0.811)$ & $(0.968)$ \\
\hline \multirow[t]{2}{*}{$\operatorname{Debt}_{(t-1)}$} & 0.802 & 1.192 & $2.046^{*}$ & $2.186^{*}$ & 0.686 & 1.532 \\
\hline & $(0.413)$ & $(0.280)$ & $(0.0698)$ & $(0.0592)$ & $(0.559)$ & $(0.259)$ \\
\hline \multirow[t]{2}{*}{ Control of corruption } & & & $-1.440^{* *}$ & $-1.192^{*}$ & & \\
\hline & & & $(0.0121)$ & $(0.0714)$ & & \\
\hline \multirow[t]{2}{*}{ Government effectiveness } & & & -0.884 & -0.753 & & \\
\hline & & & $(0.107)$ & $(0.192)$ & & \\
\hline \multirow[t]{2}{*}{ Regulatory quality } & & & $2.061^{* * *}$ & $2.230^{* * *}$ & & \\
\hline & & & $(<0.001)$ & $(0.000132)$ & & \\
\hline \multirow[t]{2}{*}{ Quality of government } & & 1.205 & & & & \\
\hline & & $(0.429)$ & & & & \\
\hline \multirow[t]{2}{*}{ Rule of Law } & & & & -0.467 & & \\
\hline & & & & $(0.462)$ & & \\
\hline \multirow[t]{2}{*}{ Index of business freedom } & & & & & 0.00471 & 0.000103 \\
\hline & & & & & $(0.626)$ & $(0.992)$ \\
\hline \multirow[t]{2}{*}{ Index of investment freedom } & & & & & $-0.0143^{* *}$ & $-0.0146^{* *}$ \\
\hline & & & & & $(0.0314)$ & $(0.0294)$ \\
\hline \multirow[t]{2}{*}{ Index of property rights protection } & & & & & & -0.0162 \\
\hline & & & & & & $(0.400)$ \\
\hline \multirow[t]{2}{*}{ Index of government integrity } & & & & & & 0.0167 \\
\hline & & & & & & $(0.232)$ \\
\hline \multirow[t]{2}{*}{ Constant } & $-160.8^{*}$ & $-183.5^{* *}$ & -71.12 & -24.74 & -153.0 & -90.83 \\
\hline & $(0.0659)$ & $(0.0479)$ & $(0.514)$ & $(0.845)$ & $(0.186)$ & $(0.469)$ \\
\hline Observations & 60 & 60 & 42 & 42 & 53 & 53 \\
\hline R-squared & 0.832 & 0.834 & 0.918 & 0.919 & 0.758 & 0.768 \\
\hline Number of countries & 3 & 3 & 3 & 3 & 3 & 3 \\
\hline \multicolumn{7}{|l|}{ GDP = gross domestic product. } \\
\hline \multicolumn{7}{|c|}{$\begin{array}{l}\text { Notes: } \\
\text { 1. All continuous variables are log-transformed. } \\
\text { 2. p-values in parentheses. }{ }^{* * * *,} \text {, denote significance at the } 1 \%, 5 \% \text {, and } 0 \% \text { level, respectively. } \\
\text { 3. Total private participation in infrastructure is the sum of private investment in infrastructure projects in the following sectors: energy, } \\
\text { telecommunication, transport, and water and sanitation. We used moving averages of } 7 \text { years for transport projects, } 9 \text { years for } \\
\text { energy projects, } 5 \text { years for telecommunication projects, and } 15 \text { years for water projects. Refer to the next section for a more detailed } \\
\text { description of our private investment variable. For a detailed description of all variables used in the regression, refer to the Appendix. }\end{array}$} \\
\hline \multicolumn{7}{|c|}{ Source: ADB estimates based on various data sources. Please refer to the Appendix for a full list of data sources. } \\
\hline
\end{tabular}




\section{Energy}

39. Our results show that private investment in South Asia's energy sector is significantly associated with the stage of development of the country, such that relatively more advanced economies attract more private sector investors. Improving regulatory quality significantly increases private investment in energy projects. Access to finance is also associated with greater private investment in energy infrastructure (column 4, Table 6).

\section{Transport}

40. Like the energy sector, our results for the transport sector show the importance of market size and economic development in attracting the private sector to invest in infrastructure (columns 1-3, Table 7). However, a higher public debt does not seem to deter these investments in the transport sector.

41. Transport projects are typically seen as risky due to long gestation periods, often ranging from 10-20 years; cost overruns during construction; and completion delays. Collier et al. (2015) find that, among countries with similar physical terrain and market connectivity, the unit costs of construction and maintenance of transport infrastructure are about 30\% higher in conflict countries and 15\% higher in countries with corruption levels above the median. Even controlling for public investment capacity and business environment does not make much of a difference. While our analysis shows that a better control on corruption in South Asia weeds out unwanted elements from transport infrastructure development, the effect is statistically insignificant (column 4, Table 7).

\section{Telecommunication}

42. Our estimates show a tendency for the private sector to spend less on telecommunication infrastructure in higher-income countries than in lower-income countries. This is because the sector is technology driven where obsolescence cost is very high (columns 1-2, Table 8), unlike energy and transport. Related to this result, setting up a large-scale basic telecommunication network in a growing country seems to offer more attractive returns than investing on the fringe in the more developed world. However, we see that private investment in telecommunication increases with market size as well as the rate of growth of the economy (columns 1-2, Table 8).

43. Interestingly, the coefficient on access to credit is statistically significant for the telecommunication sector, an indication of the relevance of domestic banks in providing credit to finance this type of infrastructure (columns 1-2, Table 8). A better quality of the government also attracts private sector infrastructure investment (column 2, Table 8). However, more open countries seem to deter foreign investors in the telecommunication sector.

44. Surprisingly, better control of corruption and improvements in the rule of law negatively impact private sector participation in the telecommunication sector (columns 3-4, Table 6). To understand this seemingly unexpected behavior, note that, against the general belief that corruption reduces economic growth by reducing private investment, some experts (for example, Méon and Sekkat 2005) argue that high corruption increases economic growth: bribes can "grease the wheels" of growth by speeding up transactions and increasing economic efficiency. Going even further, Aidt, Dutta, and Sena (2008) observe that corruption has an adverse impact on economic growth only in countries with high-quality institutions, while having no impact in countries with low-quality institutions. 
Table 6: Panel Estimation Results: Private Participation in Infrastructure, Energy Sector

\begin{tabular}{|c|c|c|c|c|c|c|}
\hline \multirow[b]{2}{*}{ Variable } & \multicolumn{6}{|c|}{ Private Participation in Infrastructure in Energy } \\
\hline & (1) & (2) & (3) & (4) & $(5)$ & (6) \\
\hline \multirow{2}{*}{ GDP per capita $_{(\mathrm{t}-1)}$} & $2.201^{* *}$ & $2.272^{* *}$ & $3.465^{*}$ & $4.144^{* *}$ & 1.924 & 2.171 \\
\hline & $(0.0452)$ & $(0.0389)$ & $(0.0566)$ & $(0.0263)$ & $(0.204)$ & $(0.161)$ \\
\hline \multirow[t]{2}{*}{ Population } & 2.728 & 1.394 & -1.817 & -7.624 & 3.917 & 0.333 \\
\hline & $(0.533)$ & $(0.758)$ & $(0.805)$ & $(0.356)$ & $(0.529)$ & $(0.958)$ \\
\hline \multirow[t]{2}{*}{ GDP growth $_{(\mathrm{t}-1)}$} & 0.127 & 0.150 & 0.147 & 0.156 & 0.270 & 0.312 \\
\hline & $(0.387)$ & $(0.313)$ & $(0.454)$ & $(0.418)$ & $(0.190)$ & $(0.127)$ \\
\hline \multirow[t]{2}{*}{ Domestic credit to private sector } & -0.0547 & 0.0315 & 1.087 & $1.703^{*}$ & 0.189 & 0.247 \\
\hline & (0.819) & $(0.900)$ & $(0.222)$ & $(0.0827)$ & $(0.648)$ & $(0.552)$ \\
\hline \multirow{2}{*}{ Inflation $_{(\mathrm{t}-1)}$} & 0.0924 & 0.0163 & 0.0440 & 0.0232 & 0.106 & 0.0693 \\
\hline & $(0.498)$ & $(0.915)$ & $(0.767)$ & $(0.873)$ & $(0.532)$ & $(0.676)$ \\
\hline \multirow{2}{*}{ Trade $_{(\mathrm{t}-1)}$} & 0.0752 & 0.298 & -0.249 & -0.201 & -0.0802 & 0.451 \\
\hline & $(0.859)$ & $(0.525)$ & $(0.650)$ & $(0.709)$ & $(0.876)$ & $(0.396)$ \\
\hline \multirow[t]{2}{*}{$\operatorname{Debt}_{(t-1)}$} & 1.065 & 0.617 & 1.682 & 1.985 & 1.415 & $1.946^{*}$ \\
\hline & $(0.195)$ & $(0.498)$ & $(0.173)$ & $(0.108)$ & $(0.182)$ & $(0.0918)$ \\
\hline \multirow[t]{2}{*}{ Control of corruption } & & & -0.624 & -0.0853 & & \\
\hline & & & $(0.303)$ & $(0.902)$ & & \\
\hline \multirow[t]{2}{*}{ Government effectiveness } & & & -0.283 & 0.00130 & & \\
\hline & & & $(0.634)$ & $(0.998)$ & & \\
\hline \multirow[t]{2}{*}{ Regulatory quality } & & & $1.001^{*}$ & $1.367^{* *}$ & & \\
\hline & & & $(0.0520)$ & $(0.0175)$ & & \\
\hline \multirow[t]{2}{*}{ Quality of government } & & -1.384 & & & & \\
\hline & & $(0.275)$ & & & & \\
\hline \multirow[t]{2}{*}{ Rule of law } & & & & -1.013 & & \\
\hline & & & & $(0.143)$ & & \\
\hline \multirow[t]{2}{*}{ Index of business freedom } & & & & & 0.0106 & 0.00171 \\
\hline & & & & & $(0.224)$ & $(0.850)$ \\
\hline \multirow[t]{2}{*}{ Index of investment freedom } & & & & & -0.000704 & -0.00170 \\
\hline & & & & & $(0.903)$ & $(0.756)$ \\
\hline \multirow[t]{2}{*}{ Index of property rights protection } & & & & & & $-0.0399^{* *}$ \\
\hline & & & & & & $(0.0171)$ \\
\hline \multirow[t]{2}{*}{ Index of government integrity } & & & & & & 0.000609 \\
\hline & & & & & & $(0.958)$ \\
\hline \multirow[t]{2}{*}{ Constant } & -54.41 & -28.34 & 15.61 & 116.3 & -77.19 & -13.82 \\
\hline & $(0.449)$ & $(0.707)$ & $(0.897)$ & $(0.394)$ & $(0.452)$ & $(0.896)$ \\
\hline Observations & 60 & 60 & 42 & 42 & 53 & 53 \\
\hline R-squared & 0.876 & 0.879 & 0.915 & 0.921 & 0.853 & 0.875 \\
\hline Number of countries & 3 & 3 & 3 & 3 & 3 & 3 \\
\hline
\end{tabular}

GDP = gross domestic product.

Notes:

1. All continuous variables are log-transformed.

2. p-values in parentheses. ${ }^{* * *},{ }^{* * *}$, denote significance at the $1 \%, 5 \%$, and $10 \%$ level, respectively.

3. For a detailed description of the variables used in the regression, refer to the Appendix.

Source: ADB estimates based on various data sources. Please refer to the appendix for a full list of data sources. 
Table 7: Panel Estimation Results: Private Participation in Infrastructure, Transport Sector

\begin{tabular}{|c|c|c|c|c|c|}
\hline \multirow[b]{2}{*}{ Variable } & \multicolumn{5}{|c|}{ Private Participation in Infrastructure in Transport } \\
\hline & (1) & (2) & (3) & (4) & (5) \\
\hline \multirow{2}{*}{ GDP per capita ${ }_{(t-1)}$} & -0.847 & -0.997 & -0.699 & 0.195 & -0.0376 \\
\hline & $(0.517)$ & $(0.463)$ & $(0.740)$ & $(0.936)$ & $(0.981)$ \\
\hline \multirow[t]{2}{*}{ Population } & $13.87^{* * *}$ & $13.76^{* * *}$ & $13.99^{*}$ & 8.781 & 8.578 \\
\hline & $(0.00469)$ & $(0.00569)$ & $(0.0902)$ & $(0.410)$ & $(0.169)$ \\
\hline \multirow[t]{2}{*}{ GDP growth $_{(\mathrm{t}-1)}$} & $0.266^{*}$ & $0.291^{*}$ & 0.0390 & 0.0510 & 0.215 \\
\hline & $(0.0547)$ & $(0.0513)$ & $(0.843)$ & $(0.799)$ & $(0.226)$ \\
\hline \multirow[t]{2}{*}{ Domestic credit to private sector } & 0.956 & 0.906 & 0.945 & 1.203 & 1.586 \\
\hline & $(0.279)$ & $(0.314)$ & $(0.380)$ & $(0.296)$ & $(0.120)$ \\
\hline \multirow{2}{*}{ Inflation, consumer prices $(\mathrm{t}-1)$} & 0.193 & 0.178 & 0.206 & 0.181 & 0.235 \\
\hline & $(0.237)$ & $(0.290)$ & $(0.211)$ & $(0.287)$ & $(0.170)$ \\
\hline \multirow[t]{2}{*}{ Trade $_{(t-1)}$} & 0.138 & 0.312 & 0.355 & 0.507 & 0.141 \\
\hline & $(0.828)$ & $(0.668)$ & $(0.604)$ & $(0.485)$ & $(0.840)$ \\
\hline \multirow[t]{2}{*}{$\operatorname{Debt}_{(t-1)}$} & $2.889^{* *}$ & $2.575^{*}$ & 2.085 & 2.440 & $3.986^{* * *}$ \\
\hline & $(0.0298)$ & $(0.0795)$ & $(0.207)$ & $(0.165)$ & $(0.00921)$ \\
\hline \multirow[t]{2}{*}{ Control of corruption } & & & -0.212 & 0.112 & \\
\hline & & & $(0.788)$ & $(0.901)$ & \\
\hline \multirow[t]{2}{*}{ Government effectiveness } & & & 0.293 & 0.396 & \\
\hline & & & $(0.643)$ & $(0.547)$ & \\
\hline \multirow[t]{2}{*}{ Regulatory quality } & & & -0.252 & 0.142 & \\
\hline & & & $(0.752)$ & $(0.882)$ & \\
\hline \multirow[t]{2}{*}{ Quality of government } & & -1.271 & & & \\
\hline & & $(0.606)$ & & & \\
\hline \multirow[t]{2}{*}{ Rule of law: estimate } & & & & -0.682 & \\
\hline & & & & $(0.453)$ & \\
\hline \multirow[t]{2}{*}{ Index of business freedom } & & & & & 0.00175 \\
\hline & & & & & $(0.880)$ \\
\hline \multirow[t]{2}{*}{ Index of investment freedom } & & & & & -0.00882 \\
\hline & & & & & $(0.262)$ \\
\hline \multicolumn{6}{|l|}{ Index of property rights protection } \\
\hline \multicolumn{6}{|l|}{ Index of government integrity } \\
\hline \multirow[t]{2}{*}{ Constant } & $-258.7^{* * *}$ & $-253.6^{* * *}$ & $-256.9^{*}$ & -166.8 & -168.3 \\
\hline & $(0.00199)$ & $(0.00292)$ & $(0.0613)$ & $(0.354)$ & $(0.109)$ \\
\hline Observations & 37 & 37 & 28 & 28 & 34 \\
\hline R-squared & 0.964 & 0.965 & 0.969 & 0.970 & 0.958 \\
\hline Number of countries & 2 & 2 & 2 & 2 & 2 \\
\hline
\end{tabular}

GDP = gross domestic product.

Notes:

1. All continuous variables are log-transformed.

2. p-values in parentheses. ${ }^{* * *}, * *$, denote significance at the $1 \%, 5 \%$, and $10 \%$ level, respectively.

3. For a detailed description of the variables used in the regression, refer to the Appendix.

Source: ADB estimates based on various data sources. Please refer to the Appendix for a full list of data sources. 
Table 8: Panel Estimation Results: Private Participation in Infrastructure, Telecommunication Sector

\begin{tabular}{|c|c|c|c|c|c|c|}
\hline \multirow[b]{2}{*}{ Variable } & \multicolumn{6}{|c|}{ Private Participation in Infrastructure in Telecommunication } \\
\hline & (1) & $(2)$ & (3) & (4) & (5) & (6) \\
\hline \multirow[t]{2}{*}{ GDP per capita $_{(\mathrm{t}-1)}$} & $-2.986^{* *}$ & $-3.128^{* * *}$ & -0.000882 & 0.773 & -1.055 & -1.315 \\
\hline & $(0.0103)$ & $(0.00576)$ & $(0.999)$ & $(0.517)$ & $(0.268)$ & $(0.201)$ \\
\hline \multirow[t]{2}{*}{ Population } & $18.42^{* * *}$ & $21.06^{* * *}$ & $9.486^{*}$ & 2.872 & $9.718^{* *}$ & $9.934^{* *}$ \\
\hline & $(0.000178)$ & $(2.79 \mathrm{e}-05)$ & $(0.0783)$ & $(0.599)$ & $(0.0166)$ & $(0.0241)$ \\
\hline \multirow[t]{2}{*}{ GDP growth $_{(\mathrm{t}-1)}$} & $0.768^{* * *}$ & $0.723^{* * *}$ & 0.169 & 0.179 & $0.396^{* * *}$ & $0.376^{* * *}$ \\
\hline & $(6.58 e-06)$ & $(1.22 \mathrm{e}-05)$ & $(0.233)$ & $(0.169)$ & $(0.00352)$ & $(0.00752)$ \\
\hline \multirow[t]{2}{*}{ Domestic credit to private sector } & $1.124^{* * *}$ & $0.953^{* * *}$ & -0.502 & 0.199 & 0.392 & $0.488^{*}$ \\
\hline & $(3.69 \mathrm{e}-05)$ & $(0.000426)$ & $(0.425)$ & $(0.754)$ & $(0.138)$ & $(0.0828)$ \\
\hline \multirow[t]{2}{*}{ Inflation $_{(\mathrm{t}-1)}$} & 0.00896 & 0.160 & $0.239^{* *}$ & $0.216^{* *}$ & 0.158 & 0.124 \\
\hline & $(0.950)$ & $(0.303)$ & $(0.0297)$ & $(0.0331)$ & $(0.144)$ & $(0.264)$ \\
\hline \multirow{2}{*}{ Trade $_{(\mathrm{t}-1)}$} & $-1.389^{* * *}$ & $-1.832^{* * *}$ & -0.0532 & 0.00150 & -0.428 & -0.273 \\
\hline & $(0.00274)$ & $(0.000311)$ & $(0.892)$ & (0.997) & $(0.192)$ & $(0.440)$ \\
\hline \multirow[t]{2}{*}{$\operatorname{Debt}_{(t-1)}$} & 1.410 & $2.296^{* *}$ & $2.258^{* *}$ & $2.603^{* * *}$ & $2.303^{* * *}$ & $2.157^{* * *}$ \\
\hline & $(0.103)$ & $(0.0155)$ & $(0.0134)$ & $(0.00284)$ & $(0.00111)$ & $(0.00650)$ \\
\hline \multirow[t]{2}{*}{ Control of corruption } & & & $-1.572^{* * *}$ & $-0.958^{* *}$ & & \\
\hline & & & $(0.000881)$ & $(0.0445)$ & & \\
\hline \multirow[t]{2}{*}{ Government effectiveness } & & & -0.267 & 0.0572 & & \\
\hline & & & $(0.529)$ & $(0.888)$ & & \\
\hline \multirow[t]{2}{*}{ Regulatory quality } & & & 0.264 & $0.682^{*}$ & & \\
\hline & & & $(0.458)$ & $(0.0689)$ & & \\
\hline \multirow[t]{2}{*}{ Quality of government } & & $2.741^{* *}$ & & & & \\
\hline & & $(0.0355)$ & & & & \\
\hline \multirow[t]{2}{*}{ Rule of law: estimate } & & & & $-1.154^{* *}$ & & \\
\hline & & & & $(0.0156)$ & & \\
\hline \multirow[t]{2}{*}{ Index of business freedom } & & & & & 0.00838 & 0.00690 \\
\hline & & & & & $(0.128)$ & $(0.255)$ \\
\hline \multirow[t]{2}{*}{ Index of investment freedom } & & & & & $-0.0150^{* * *}$ & $-0.0152^{* * *}$ \\
\hline & & & & & $(0.000173)$ & $(0.000152)$ \\
\hline \multirow[t]{2}{*}{ Index of property rights protection } & & & & & & -0.00851 \\
\hline & & & & & & $(0.430)$ \\
\hline \multirow[t]{2}{*}{ Index of government integrity } & & & & & & -0.00664 \\
\hline & & & & & & $(0.394)$ \\
\hline \multirow[t]{2}{*}{ Constant } & $-307.4^{* * *}$ & $-359.0^{* * *}$ & $-167.4^{*}$ & -52.69 & $-164 \cdot 3^{* *}$ & $-165.8^{* *}$ \\
\hline & $(0.000142)$ & $(1.92 \mathrm{e}-05)$ & $(0.0582)$ & $(0.561)$ & $(0.0141)$ & $(0.0223)$ \\
\hline Observations & 60 & 60 & 42 & 42 & 53 & 53 \\
\hline R-squared & 0.849 & 0.862 & 0.905 & 0.923 & 0.844 & 0.852 \\
\hline Number of countries & 3 & 3 & 3 & 3 & 3 & 3 \\
\hline
\end{tabular}

GDP = gross domestic product.

Notes:

1. All continuous variables are log-transformed.

2. p-values in parentheses. ${ }^{* * *},{ }^{* * *}$, denote significance at the $1 \%, 5 \%$, and $10 \%$ level, respectively.

3. For a detailed description of the variables used in the regression, refer to the Appendix.

Source: ADB estimates based on various data sources. Please refer to the Appendix for a full list of data sources. 


\section{CONCLUSIONS AND POLICY IMPLICATIONS}

45. Good quality infrastructure and efficient infrastructure services, especially roads, electricity, and telecommunication systems, help raise productivity, improve industry competitiveness, and sustain growth over the medium term. Mainly financed from public resources, basic infrastructure services of greatest benefit to the poor, such as access to drinking water, sanitation facilities, electricity, and roads remain inadequate and of poor quality in South Asia.

46. Improving the quality of and access to infrastructure services require significant increases in investment spending on operations and maintenance. Although there is a strong case for governments to take responsibility for essential infrastructure services, the budgetary envelope of South Asian governments is limited. To some extent, this can be addressed through stronger domestic resource mobilization by identifying new sources of finance (e.g., using tax revenues to refinance infrastructure, institutional investor funds). But increased allocation of public resources alone is not enough. The subregion needs to improve its efficiency in the use of public funds too, e.g., by improving administration and dealing with governance issues, which are at the core of service delivery problems.

47. The promotion of infrastructure investment also requires greater leverage of private finance. Private sector infrastructure investment depends on the quality of public institutions and effective regulatory framework for enforceability of contracts and resolution of insolvency, among other things. Controlling for economic characteristics of a country, our results show that institutional variables, such as governance quality, positively impact overall and private investment in infrastructure. These results also hold when data is disaggregated at the sectoral level. Such findings highlight the importance of a supportive enabling environment for more active private participation. South Asian countries have made progress in implementing policy and regulatory reforms to improve the prospects for private infrastructure investment, but progress has been uneven and poor compared with other regions.

48. Our analysis shows the significance of access to credit for overall infrastructure investment and that in the telecommunication sector. Bank loans dominate private infrastructure finance in South Asia and there is a greater role for bond financing to complement banks. Also needed is a deepening of capital markets to help channel the region's substantial savings into productive infrastructure to sustain growth. 


\section{APPENDIX: DEFINITION OF VARIABLES}

\begin{tabular}{|c|c|c|c|}
\hline Variable & Scale & Definition & Source \\
\hline Public capital stock & $\begin{array}{l}\text { Constant PPP } \\
\text { United States } \\
\text { dollars }\end{array}$ & $\begin{array}{l}\text { Capital stock of the general government. Constructed } \\
\text { based on general government investment flows (gross } \\
\text { fixed capital formation). }\end{array}$ & $\begin{array}{l}\text { IMF, Fiscal Affairs } \\
\text { Department }\end{array}$ \\
\hline $\begin{array}{l}\text { Investment in } \\
\text { energy with private } \\
\text { participation }\end{array}$ & $\begin{array}{l}\text { United States } \\
\text { dollars }\end{array}$ & $\begin{array}{l}\text { Commitments to infrastructure projects in energy } \\
\text { (electricity and natural gas: generation, transmission, } \\
\text { and distribution) that have reached financial closure and } \\
\text { directly or indirectly serve the public. Movable assets and } \\
\text { small projects such as windmills are excluded. The types } \\
\text { of projects included are management and lease contracts, } \\
\text { operation and management contracts with major capital } \\
\text { expenditure, greenfield projects (in which a private entity } \\
\text { or a public-private joint venture builds and operates a } \\
\text { new facility), and divestitures. Investment commitments } \\
\text { are the sum of investments in facilities and investments } \\
\text { in government assets. Investments in facilities are the } \\
\text { resources the project company commits to invest during } \\
\text { the contract period either in new facilities or in expansion } \\
\text { and modernization of existing facilities. Investments in } \\
\text { government assets are the resources the project company } \\
\text { spends on acquiring government assets such as SOEs, } \\
\text { rights to provide services in a specific area, or the use of } \\
\text { specific radio spectrums. }\end{array}$ & $\begin{array}{l}\text { PPI database, World } \\
\text { Bank }\end{array}$ \\
\hline $\begin{array}{l}\text { Investment in } \\
\text { telecommunication } \\
\text { with private } \\
\text { participation }\end{array}$ & $\begin{array}{l}\text { United States } \\
\text { dollars }\end{array}$ & $\begin{array}{l}\text { Commitments to infrastructure projects in } \\
\text { telecommunication that have reached financial closure } \\
\text { and directly or indirectly serve the public. Movable } \\
\text { assets and small projects are excluded. The types of } \\
\text { projects included are management and lease contracts, } \\
\text { operation and management contracts with major capital } \\
\text { expenditure, greenfield projects (in which a private entity } \\
\text { or a public-private joint venture builds and operates a } \\
\text { new facility), and divestitures. Investment commitments } \\
\text { are the sum of investments in facilities and investments } \\
\text { in government assets. Investments in facilities are the } \\
\text { resources the project company commits to invest during } \\
\text { the contract period either in new facilities or in expansion } \\
\text { and modernization of existing facilities. Investments in } \\
\text { government assets are the resources the project company } \\
\text { spends on acquiring government assets such as SOEs, } \\
\text { rights to provide services in a specific area, or the use of } \\
\text { specific radio spectrums. }\end{array}$ & $\begin{array}{l}\text { PPI database, World } \\
\text { Bank }\end{array}$ \\
\hline
\end{tabular}


Table continued

\begin{tabular}{|c|c|c|c|}
\hline Variable & Scale & Definition & Source \\
\hline $\begin{array}{l}\text { Investment } \\
\text { in transport } \\
\text { with private } \\
\text { participation }\end{array}$ & $\begin{array}{l}\text { United States } \\
\text { dollars }\end{array}$ & $\begin{array}{l}\text { Commitments to infrastructure projects in transport that } \\
\text { have reached financial closure and directly or indirectly } \\
\text { serve the public. Movable assets and small projects are } \\
\text { excluded. The types of projects included are management } \\
\text { and lease contracts, operation and management contracts } \\
\text { with major capital expenditure, greenfield projects (in } \\
\text { which a private entity or a public-private joint venture } \\
\text { builds and operates a new facility), and divestitures. } \\
\text { Investment commitments are the sum of investments } \\
\text { in facilities and investments in government assets. } \\
\text { Investments in facilities are the resources the project } \\
\text { company commits to invest during the contract period } \\
\text { either in new facilities or in expansion and modernization } \\
\text { of existing facilities. Investments in government assets are } \\
\text { the resources the project company spends on acquiring } \\
\text { government assets such as SOEs, rights to provide services } \\
\text { in a specific area, or the use of specific radio spectrums. }\end{array}$ & $\begin{array}{l}\text { PPI database, World } \\
\text { Bank }\end{array}$ \\
\hline
\end{tabular}

\begin{tabular}{|c|c|c|c|}
\hline $\begin{array}{l}\text { Investment in water } \\
\text { and sanitation } \\
\text { with private } \\
\text { participation }\end{array}$ & $\begin{array}{l}\text { United States } \\
\text { dollars }\end{array}$ & $\begin{array}{l}\text { Commitments to infrastructure projects in water and } \\
\text { sanitation that have reached financial closure and directly } \\
\text { or indirectly serve the public. Movable assets, incinerators, } \\
\text { standalone solid waste projects, and small projects are } \\
\text { excluded. The types of projects included are management } \\
\text { and lease contracts, operation and management contracts } \\
\text { with major capital expenditure, greenfield projects (in } \\
\text { which a private entity or a public-private joint venture } \\
\text { builds and operates a new facility), and divestitures. } \\
\text { Investment commitments are the sum of investments } \\
\text { in facilities and investments in government assets. } \\
\text { Investments in facilities are the resources the project } \\
\text { company commits to invest during the contract period } \\
\text { either in new facilities or in expansion and modernization } \\
\text { of existing facilities. Investments in government assets are } \\
\text { the resources the project company spends on acquiring } \\
\text { government assets such as SOEs, rights to provide services } \\
\text { in a specific area, or the use of specific radio spectrums. }\end{array}$ & $\begin{array}{l}\text { PPI database, World } \\
\text { Bank }\end{array}$ \\
\hline GDP per capita & $\begin{array}{l}\text { Constant PPP } \\
\text { United States } \\
\text { dollars, per } \\
\text { person }\end{array}$ & $\begin{array}{l}\text { GDP at purchaser's prices is the sum of gross value added } \\
\text { by all resident producers in the economy plus any product } \\
\text { taxes and minus any subsidies not included in the value of } \\
\text { the products. It is calculated without making deductions } \\
\text { for depreciation of fabricated assets or for depletion and } \\
\text { degradation of natural resources. }\end{array}$ & $\begin{array}{l}\text { World Bank, World } \\
\text { Development } \\
\text { Indicators }\end{array}$ \\
\hline Population & Million persons & $\begin{array}{l}\text { Based on the de facto definition of population, which } \\
\text { counts all residents regardless of legal status or citizenship. } \\
\text { The values shown are midyear estimates. }\end{array}$ & $\begin{array}{l}\text { World Bank, World } \\
\text { Development } \\
\text { Indicators }\end{array}$ \\
\hline GDP growth & $\begin{array}{l}\text { Annual in } \\
\text { percent }\end{array}$ & $\begin{array}{l}\text { Annual percentage growth rate of GDP at market prices } \\
\text { based on constant local currency. Aggregates are based on } \\
\text { constant } 2010 \text { United States dollars. }\end{array}$ & $\begin{array}{l}\text { World Bank, World } \\
\text { Development } \\
\text { Indicators }\end{array}$ \\
\hline
\end{tabular}


Table continued

\begin{tabular}{|c|c|c|c|}
\hline Variable & Scale & Definition & Source \\
\hline $\begin{array}{l}\text { Domestic credit to } \\
\text { private sector }\end{array}$ & Share of GDP & $\begin{array}{l}\text { Financial resources provided to the private sector by } \\
\text { financial corporations, such as through loans, purchases } \\
\text { of nonequity securities, and trade credits and other } \\
\text { accounts receivable, that establish a claim for repayment. } \\
\text { For some countries, these claims include credit to } \\
\text { public enterprises. The financial corporations include } \\
\text { monetary authorities and deposit money banks, as well } \\
\text { as other financial corporations where data are available } \\
\text { (including corporations that do not accept transferable } \\
\text { deposits, but do incur such liabilities as time and savings } \\
\text { deposits). Examples of other financial corporations are } \\
\text { finance and leasing companies, money lenders, insurance } \\
\text { corporations, pension funds, and foreign exchange } \\
\text { companies. }\end{array}$ & $\begin{array}{l}\text { World Bank, World } \\
\text { Development } \\
\text { Indicators }\end{array}$ \\
\hline $\begin{array}{l}\text { Inflation, consumer } \\
\text { prices }\end{array}$ & $\begin{array}{l}\text { Year-on-year } \\
\text { percent change }\end{array}$ & $\begin{array}{l}\text { Inflation as measured by the consumer price index reflects } \\
\text { the annual percentage change in the cost to the average } \\
\text { consumer of acquiring a basket of goods and services that } \\
\text { may be fixed or changed at specified intervals, such as } \\
\text { yearly. The Laspeyres formula is generally used. }\end{array}$ & $\begin{array}{l}\text { World Bank, World } \\
\text { Development } \\
\text { Indicators }\end{array}$ \\
\hline Trade openness & Share of GDP & Sum of exports and imports of goods and services. & $\begin{array}{l}\text { World Bank, World } \\
\text { Development } \\
\text { Indicators }\end{array}$ \\
\hline Debt & Share of GDP & $\begin{array}{l}\text { Gross debt consists of all liabilities that require payment or } \\
\text { payments of interest and/or principal by the debtor to the } \\
\text { creditor at a date or dates in the future. This includes debt } \\
\text { liabilities in the form of special drawing rights, currency } \\
\text { and deposits, debt securities, loans, insurance, pensions } \\
\text { and standardized guarantee schemes, and other accounts } \\
\text { payable. Thus, all liabilities in the GFSM } 2001 \text { system are } \\
\text { debt, except for equity and investment fund shares and } \\
\text { financial derivatives, and employee stock options. Debt } \\
\text { can be valued at current market, nominal, or face values } \\
\text { (GFSM 2001, paragraph 7.110). }\end{array}$ & $\begin{array}{l}\text { IMF, World } \\
\text { Economic Outlook }\end{array}$ \\
\hline $\begin{array}{l}\text { Quality of } \\
\text { government }\end{array}$ & $\begin{array}{l}\text { o-1. Higher } \\
\text { values indicate } \\
\text { higher quality of } \\
\text { government. }\end{array}$ & $\begin{array}{l}\text { Mean value of the International Country Risk } \\
\text { Guide variables "Corruption," "Law and Order," and } \\
\text { "Bureaucracy Quality." }\end{array}$ & $\begin{array}{l}\text { International } \\
\text { Country Risk Guide }\end{array}$ \\
\hline $\begin{array}{l}\text { Control of } \\
\text { corruption }\end{array}$ & $\begin{array}{l}\text { Units of a } \\
\text { standard normal } \\
\text { distribution, } \\
\text { for example, } \\
\text { ranging from } \\
\text { approximately } \\
2.5 \text { to } 2.5\end{array}$ & $\begin{array}{l}\text { Captures perceptions of the extent to which public power } \\
\text { is exercised for private gain, including both petty and } \\
\text { grand forms of corruption, as well as "capture" of the state } \\
\text { by elites and private interests. Estimate gives the country's } \\
\text { score on the aggregate indicator. }\end{array}$ & \multirow{2}{*}{$\begin{array}{l}\text { Kaufmann D., } \\
\text { A. Kraay, and M. } \\
\text { Mastruzzi (2010), } \\
\text { The Worldwide } \\
\text { Governance } \\
\text { Indicators: } \\
\text { Methodology and } \\
\text { Analytical Issues, } \\
\text { www.govindicators. } \\
\text { org }\end{array}$} \\
\hline $\begin{array}{l}\text { Government } \\
\text { effectiveness }\end{array}$ & $\begin{array}{l}\text { Units of a } \\
\text { standard normal } \\
\text { distribution, } \\
\text { for example, } \\
\text { ranging from } \\
\text { approximately } \\
2.5 \text { to } 2.5\end{array}$ & $\begin{array}{l}\text { Captures perceptions of the extent to which public power } \\
\text { is exercised for private gain, including both petty and } \\
\text { grand forms of corruption, as well as "capture" of the state } \\
\text { by elites and private interests. Estimate gives the country's } \\
\text { score on the aggregate indicator. }\end{array}$ & \\
\hline
\end{tabular}


Table continued

\begin{tabular}{|c|c|c|c|}
\hline Variable & Scale & Definition & Source \\
\hline $\begin{array}{l}\text { Regulatory quality: } \\
\text { estimate }\end{array}$ & $\begin{array}{l}\text { Units of a } \\
\text { standard normal } \\
\text { distribution, } \\
\text { for example, } \\
\text { ranging from } \\
\text { approximately } \\
2.5 \text { to } 2.5\end{array}$ & $\begin{array}{l}\text { Captures perceptions of the ability of the government to } \\
\text { formulate and implement sound policies and regulations } \\
\text { that permit and promote private sector development. } \\
\text { Estimate gives the country's score on the aggregate } \\
\text { indicator. }\end{array}$ & \\
\hline $\begin{array}{l}\text { Rule of law: } \\
\text { estimate }\end{array}$ & $\begin{array}{l}\text { Units of a } \\
\text { standard normal } \\
\text { distribution, } \\
\text { for example, } \\
\text { ranging from } \\
\text { approximately } \\
2.5 \text { to } 2.5\end{array}$ & $\begin{array}{l}\text { Captures perceptions of the extent to which agents have } \\
\text { confidence in and abide by the rules of society, and the } \\
\text { quality of contract enforcement, property rights, the } \\
\text { police, and the courts, as well as the likelihood of crime } \\
\text { and violence. Estimate gives the country's score on the } \\
\text { aggregate indicator. }\end{array}$ & \\
\hline $\begin{array}{l}\text { Index of business } \\
\text { freedom }\end{array}$ & $\begin{array}{l}\text { O-100. Higher } \\
\text { levels of the } \\
\text { index indicate } \\
\text { more investment } \\
\text { freedom, for } \\
\text { example, fewer } \\
\text { constraints. }\end{array}$ & $\begin{array}{l}\text { The business freedom component measures the extent } \\
\text { to which the regulatory and infrastructure environments } \\
\text { constrain the efficient operation of businesses. The } \\
\text { quantitative score is derived from an array of factors } \\
\text { that affect the ease of starting, operating, and closing a } \\
\text { business. }\end{array}$ & $\begin{array}{l}\text { Index of Economic } \\
\text { Freedom } 2017 \\
\text { (Heritage } \\
\text { Foundation) }\end{array}$ \\
\hline $\begin{array}{l}\text { Index of investment } \\
\text { freedom }\end{array}$ & $\begin{array}{l}\text { O-100. Higher } \\
\text { levels of the } \\
\text { index indicate } \\
\text { more investment } \\
\text { freedom, for } \\
\text { example, fewer } \\
\text { constraints. }\end{array}$ & $\begin{array}{l}\text { The index evaluates a variety of regulatory restrictions that } \\
\text { typically are imposed on investment. Points, are deducted } \\
\text { from the ideal score of } 100 \text { for each of the restrictions } \\
\text { found in a country's investment regime. Investment } \\
\text { restrictions include national treatment of foreign } \\
\text { investment, foreign investment code, restrictions on } \\
\text { land ownership, sectoral investment restrictions, foreign } \\
\text { exchange controls, and capital controls. }\end{array}$ & \\
\hline \multirow[t]{2}{*}{$\begin{array}{l}\text { Index of property } \\
\text { rights protection }\end{array}$} & $\begin{array}{l}\text { o-10o. Higher } \\
\text { levels of the } \\
\text { index indicate } \\
\text { more investment } \\
\text { freedom, for } \\
\text { example, fewer } \\
\text { constraints. }\end{array}$ & $\begin{array}{l}\text { The property rights component assesses the extent to } \\
\text { which a country's legal framework allows individuals to } \\
\text { freely accumulate private property, secured by clear laws } \\
\text { that are enforced effectively by the government. Relying } \\
\text { on a mix of survey data and independent assessments, it } \\
\text { provides a quantifiable measure of the degree to which } \\
\text { a country's laws protect private property rights and the } \\
\text { extent to which those laws are respected. It also assesses } \\
\text { the likelihood that private property will be expropriated by } \\
\text { the state. }\end{array}$ & \\
\hline & & $\begin{array}{l}\text { The more effective the legal protection of property, the } \\
\text { higher a country's score will be. Similarly, the greater the } \\
\text { chances of government expropriation of property, the } \\
\text { lower a country's score will be. }\end{array}$ & \\
\hline $\begin{array}{l}\text { Index of } \\
\text { government } \\
\text { integrity }\end{array}$ & $\begin{array}{l}\text { O-100. Higher } \\
\text { levels of the } \\
\text { index indicate } \\
\text { more investment } \\
\text { freedom, for } \\
\text { example, fewer } \\
\text { constraints. }\end{array}$ & $\begin{array}{l}\text { Corruption erodes economic freedom by introducing } \\
\text { insecurity and uncertainty into economic relations. Of } \\
\text { greatest concern is the systemic corruption of government } \\
\text { institutions and decision-making by such practices } \\
\text { as bribery, extortion, nepotism, cronyism, patronage, } \\
\text { embezzlement, and graft. The lack of government integrity } \\
\text { caused by such practices reduces economic vitality by } \\
\text { increasing costs and shifting resources into unproductive } \\
\text { lobbying activities. }\end{array}$ & \\
\hline
\end{tabular}

GDP = gross domestic product, GFSM = Government Finance Statistics Manual, IMF = International Monetary Fund, $\mathrm{PPI}=$ private participation in infrastructure, $\mathrm{PPP}=$ public-private partnership, $\mathrm{SOE}=$ state-owned enterprise.

Source(s): This table shows variable definitions and source of data. Data sources are found in the 4th column of the table. 


\section{REFERENCES}

Asian Development Bank (ADB). 2008. Public-Private Partnership Handbook. Manila.

-_- 2017a. Meeting Asia’s Infrastructure Needs. Manila.

-_- 2017b. Public-Private Partnership Monitor. Manila.

- - - 2017c. ADB Launches First Annual Report Monitoring Progress of PPP Environment in Member Countries. News Release. 23 November. https://www.adb.org/news/adb-launches-first-annual-reportmonitoring-progress-ppp-environment-member-countries.

Asian Development Bank Institute (ADBI). 2009. Seamless Asia. Manila.

Aidt, T., J. Dutta, and V. Sena. 2008. Governance Regimes, Corruption and Growth: Theory and Evidence. Journal of Comparative Economics. 36. pp. 195-220.

Allcott, H., A. Collard-Wexler, and S.D. O'Connell. 2016. How Do Electricity Shortages Affect Industry? Evidence from India. American Economic Review.106(3). pp. 587-624

Auriol, E., and T. Søreide. 2017. An Economic Analysis of Debarment. International Review of Law and Economics. Vol. 50. pp. 36-49. Elsevier.

Berg, C. N., et al. 2015. Transport Policies and Development. Policy Research Working Paper. 7366. Washington, DC: World Bank.

Brook, P. J., and S. Smith (eds). 2000. Energy Services for the World's Poor: Energy and Development Report 2000. Washington, DC: World Bank.

Calderón, C., E. Moral-Benito, and L. Servén. 2011. Is Infrastructure Capital Productive? A Dynamic Heterogeneous Approach. WPS. 5682. Washington, DC: World Bank.

Collier, P., M. Kirchberger, and M. Söderbom. 2015. The Cost of Road Infrastructure in Low and Middle Income Countries. Policy Research Working Paper. WPS 7408. Washington, DC: World Bank.

Economist Intelligence Unit. 2014. Evaluating the Environment for Public-Private Partnerships (PPP) in Asia-Pacific. www.eiu.com/Asialnfrascope2014.

El-Ashram, A. 2017. Public Investment Scaling Up and Debt-Sustainability: The Case of Energy Sector Investments in the Caribbean. International Monetary Fund (IMF) Working Paper. WP/17/138. Washington, DC.

International Monetary Fund. 2015. Making Public Investment More Efficient. Washington, DC.

Inderst, G. 2016. Infrastructure Investment, Private Finance, and Institutional Investors: Asia from a Global Perspective. ADBI Working Paper Series. No. 555. Tokyo.

Jordan-Tank, M. 2017. Why Infrastructure Development Needs More from the Private Sector. European Bank for Reconstruction and Development. News. 9 Mar. http://www.ebrd.com/news/2017/whyinfrastructure-development-needs-more-from-the-private-sector.html.

Keefer, P., and S. Knack. 2007. Boondoggles, Rent-Seeking and Political Checks and Balances: Public Investment under Unaccountable Governments. Review of Economics and Statistics. 89. 566-572. 
Kose, M. A., et al. 2017. A Cross-Country Database of Fiscal Space. Policy Research Working Paper. 8157. Washington, DC: World Bank. http://www.worldbank.org/en/data/interactive/2017/07/26/fiscal-spacedata.

Lavado, R. F., and G. A. Domingo. 2015. Public Service Spending: Efficiency and Distributional ImpactLessons from Asia. Asian Development Bank Economics Working Paper Series. No. 435. Manila.

Méon, P.-G., and K. Sekkat. 2005. Does Corruption Grease or Sand the Wheels of Growth? Public Choice. 122(1-2). pp. 69-97.

Moszoro, et al. 2015. What Drives Private Participation in Infrastructure in Developing Countries? Public Private Partnerships for Infrastructure and Business Development. pp. 19-44.United States: Palgrave Macmillan.

Pritchett, L. 2000. The Tyranny of Concepts: CUDIE (Cumulated, Depreciated, Investment Effort)Is Not Capital. Journal of Economic Growth. 5 (4): 361-84.

Romero-Torres, J., S. Bhatia, and S. Sural. 2017. Securitization in India: Managing Capital Constraints and Creating Liquidity to Fund Infrastructure Assets. Manila: ADB.

Tanzi, V., and H. Davoodi. 1997. Corruption, Public Investment and Growth. IMF Working Paper. WP/97/139. Washington, DC.

Troesken, Werner. 2006. Regime Change and Corruption: A History of Public Utility Regulation. Chapter 8. In Edward L. Glaeser and Claudia Goldin, eds. Corruption and Reform: Lessons from America's Economic History. http://www.nber.org/chapters/c9986. University of Chicago Press. 


\section{Infrastructure Financing in South Asia}

South Asia seems to defy the theory that development of infrastructure is required for sustained economic growth. Despite the severe and persistent shortage of quality infrastructure, it is the fastest growing region in the world. This paper argues that the trend cannot continue. To sustain growth and deal with climate change, South Asia needs to invest almost $9 \%$ of its gross domestic product on infrastructure development over 2016-2030, higher than most other subregions of Asia. This paper discusses public and private sector financing of infrastructure, and examines the factors driving infrastructure investment.

\section{About the Asian Development Bank}

ADB is committed to achieving a prosperous, inclusive, resilient, and sustainable Asia and the Pacific, while sustaining its efforts to eradicate extreme poverty. Established in 1966, it is owned by 67 members48 from the region. Its main instruments for helping its developing member countries are policy dialogue, loans, equity investments, guarantees, grants, and technical assistance. 